\title{
Roll the Dice-Let's See If Differences Really Matter! Accounting Judgments and Sustainable Decisions in the Light of a Gender and Age Analysis
}

\author{
Victoria Bogdan ${ }^{1}$, Delia Deliu ${ }^{2, * \mathbb{D}}$, Tomina Săveanu ${ }^{3}$, Olimpia Iuliana Ban ${ }^{4}$ and \\ Dorina Nicoleta Popa ${ }^{1}$ \\ 1 Department of Finance and Accounting, Faculty of Economic Sciences, University of Oradea, \\ 410087 Oradea, Romania; vbogdan@uoradea.ro (V.B.); dlezeu@uoradea.ro (D.N.P.) \\ 2 Department of Accounting and Audit, Faculty of Economics and Business Administration, West University \\ of Timişoara, 300115 Timişoara, Romania \\ 3 Research Centre for Competitiveness and Sustainable Development, Faculty of Economic Sciences, \\ University of Oradea, 410087 Oradea, Romania; tsaveanu@uoradea.ro \\ 4 Department of Business Economics, Faculty of Economic Sciences, University of Oradea, \\ 410087 Oradea, Romania; oban@uoradea.ro \\ * Correspondence: delia.deliu@e-uvt.ro
}

Received: 18 August 2020; Accepted: 7 September 2020; Published: 11 September 2020

\begin{abstract}
This research aims to investigate whether gender and age of Professional Accountants influence their opinion upon accounting judgments and sustainable decision-making. Through a questionnaire, accountants were interrogated about their education, professional profile, age, gender, personality traits, and their perception on accounting judgment and professional behavior. On one hand, results showed that women accountants are more inclined to comply with accounting regulations and more interested in following an ethical behavior. Moreover, women tend to be more interested in fulfilling managers' expectations and more willing to collaborate. On the other hand, men accountants proved to be more independent in judgments and more skeptical. Furthermore, men have a greater propensity to make accurate, sustainable judgments, considering the evaluation of goodwill as more important than women. However, no correlations were found between age, gender and accountants' perception on the theoretical framework of professional accounting judgment. As the age of accountants grows, the compliance degree to regulations increases. This study adds value to gender accounting literature by the way it examines accountants' behavior and perception towards accounting judgments and sustainable decisions in correlation to gender diversity and age.
\end{abstract}

Keywords: professional accountants; professional accounting judgment; gender diversity; gender stereotypes; SDG 5; age dissimilarities; sustainable decisions; perceptions

\section{Introduction}

The study of gender differences across different sciences has always been of interest since the scientific analysis of the original sin.

However, the international feminist movement has generated an increase in interest in gender literature in the 1970s. Thus, as Lehman observed, gender literature is concerned with investigating inequalities in male-dominated jobs, gender stereotypes, as well as under-representation of women at work, professions, and policy-making bodies [1]. The next decade brought an increase in gender research in the economic and management literature. As reported by the United Nations Educational, Scientific and Cultural Organization (UNESCO), a large disparity is found in the partaking of women in science, technology, engineering and mathematics (STEM), in particular at the more advanced career 
levels [2]. As reported by the United Nations' Economic and Social Council (ECOSOC), a gender perspective finds its correspondent in the "process of assessing the implications for women and men of any planned action, including legislation, policies or programs in all areas and at all levels" [3].

In our times, gender inequality is endemic to the workplace, as emphasized by UNESCO, even though increased diversity makes sense in various ways, including when measured in economic terms [2].

Sustainable Development Goal Five (SDG 5) solicits countries worldwide to reach gender equality, as well as to empower women, as presented by United Nations General Assembly [4].

In social sciences, women's empowerment-in general-finds its correspondent in the attainment of facilitating resources to exercise agency, or the capability to make life decisions even though these choices are either narrowed or constrained, as Kabeer (1999) outlines [5]. This implies human resources (i.e., knowledge, skills, abilities, sense of entitlement, self-esteem), as delineated by Kabeer (1998) and Taylor and Pereznieto (2014) [6,7], as well as economic resources (i.e., market work, earnings, financial and physical resources), as presented by Kabeer (2008) [8], respectively social resources (i.e., the capability to adhere with non-family associates in order to improve their economic bustle and pecuniary rights), as demarcated by Kabeer and Huq (2010) and Kabeer $(2011)[9,10]$.

In this context, SDG 5 emphasizes the significance of women's economic empowerment, demanding "equal rights to economic resources" (Target 5.A), along with necessitating "full and effective participation ... at all levels of decision-making ( . . . ) in economic life" (Target 5.5) [11].

In time, gender stratification theory has developed and the existence of gender inequalities in a social system have proven to be the source of differences in the degree of responsibilities, as a tendency clearly could be recognized lying in the fact that, in a social system, one group may become dominant and may suppress the other group [12,13]. As Tiron-Tudor and Faragalla (2018) outlined, gender stratification theory concepts like glass-ceiling, differential access and occupational distribution have emerged [14]. Thus, as previously depicted in the Hays Gender Diversity Report (2017), organizations can be more successful if they upsurge the gender diversity of the top and middle-management [15]. Despite the fact that most previous work has clinched that the gender gap is narrower today than it was in the past, Holman et al. (2018) emphasized that many research fields (i.e., computer science, surgery, physics, mathematics, etc.) will not reach gender parity this century [16]. Within this frame of reference, Banchefsky \& Park (2018), as well as Castaño et al. (2020) and Moè et al. (2020) have recognized that women are underrepresented in middle and top-management positions, such as those related to STEM field careers, one of the causes for this lying on negative gender ideologies [17] and gender stereotypes [18,19]. In this context, it is imperative to address stereotypes, bias and beliefs related to gender, since they could straightforwardly support future gender segregation at the workplace.

Conversely, Hitka et al. (2018) identified noteworthy dissimilarities in motivation factors amid (Slovak) employees, most of them linked to their education and gender [20]. As far as the accounting literature is concerned, consistent with Parker (2008), the accounting profession has called for gender blindness, preserving the myth of "gender-neutral accounting" owing to accounting's "objectivity" and "rationality" [21]. It is well known, however, that accounting methods and procedures have been associated with male physiognomies for ages, as outlined by Siboni et al. (2016) [22]. In this respect, both Hines (1992) and Broadbent (1998) agree that the bottom line of accounting practices find their correspondent in masculine tenets and values, inhibiting and hindering feminine merits, while undervaluing the emotional, sustainable facet $[23,24]$. More recent studies conducted by Parker (2015) and Broadbent (2016) highlighted the idea that gender issues have been lately acknowledged as a zone where accounting academics ought to engage more $[25,26]$.

In the light of very recent reported research undertaken by Núñez et al. (2020) it is conceivable that social economy entities contribute to the accomplishment of SDG 5 by displaying higher female participation, more stable jobs, and a lower degree of the glass-ceiling phenomenon [27]. 
Therefore, a number of questions regarding gender stereotypes, respectively the impact of gender diversity, as well as age dissimilarities in professional reasoning, especially when talking about sustainable decisions, still remain to be addressed.

In this context, this paper aims to identify and group research topics from the existing accounting literature based on the gender issues discussed in connection with accounting and to examine gender in relation to professional accounting judgment. As a result of examining the current research trend on gender and accounting we identified the following main research streams in the accounting literature: gender differences in accounting education; gender issues in accounting profession; the intercorrelation between gender diversity and business performance; gender differences in sustainable financial reporting decision-making; gender issues in ethical behavior and accounting judgments, respectively gender differences in academic accounting research. Based on the results obtained from previous studies, we have investigated the correlations between age and gender on the fundamentals of accounting judgments, as well as the influence of age and gender upon the theoretical framework of accounting judgment $[28,29]$.

The needs of stakeholders and decision-makers are shifting the role of the Professional Accountant from being a provider of financial information to becoming an active participant in the decision-making process. These ever-changing expectations placed on the Professional Accountant result in a paradigm shift towards providing value-added services, which will contribute to the success and business sustainability of the organization.

In this background, taking all these into consideration, we have analyzed whether there are significant variances between men and women regarding the exercise of professional reasoning and accounting judgments in consulting the entity's management, the skepticism regarding the nature of economic events and transactions that require an accounting judgment, the interest pursued by Professional Accountants in choosing and applying accounting policies, the hierarchy of the most important features of an appropriate professional accounting judgment and the hierarchy of the most relevant accounting issues that require an appropriate accounting judgment.

On one hand, it is obvious that companies can no longer perform short-term wins over following a sustainable strategy, especially as European Union's (EU) policymakers have started an ambitious legislative push towards a more sustainable economy. Accountants must provide transparency that is vital for the stability of Europe's financial system and for moving from short-term investments to sustainable economic growth. Hence, accounting is a natural starting point. Henceforth, Professional Accountants contribute to sustainable finances through corporate reporting (to cover long-term risks), corporate governance (to concentrate on long-term value creation), as well as through auditing (to provide trust to stakeholders). Henceforward, Professional Accountants can be a strategic partner for companies' transition towards a more sustainable future by means of: providing better corporate information and offering independent assurance, assigning costs to negative impacts on the environment and society, encouraging Environmental, Social and Governance (ESG) goals and helping entities in implementing ESG regulations, performing on-the-ground monitoring and measuring, as well as identifying ways to reward sustainable policies and sustainable decisions.

On the other hand, in a similar vein with Siboni et al. (2016), this study can be placed among the works concerned with the investigation of lived experience of female accountants activating in various roles, positions and organizations (economic entities, professional accounting bodies, institutions of higher education, etc.) [22], in order to comprehend not only the impediments and hindrances they come across, but also to scrutinize the dissimilarities between the discernments of men and women as regards accounting information, so as to assess whether there is room for change in the switch from traditional accounting information systems to sustainable accounting information systems.

\section{Literature Review and Hypothesis Development}

There have been numerous studies to investigate the analysis of gender differences in correlation with accounting education matters [30-32]. Ameen et al. (1996) explored the potential relations 
between gender and the inclination to accept unethical academic behaviour and found that female students are less cynical and not so frequently engaged in academic dishonesty [30], while Sadler and Barac (2005) proved that male students are expected to act unethically more than their female colleagues [31]. Wessels and Steenkamp (2009) surveyed African students' opinions and established no variances among genders in the accounting profession [32]. As reported by Halabi et al. (2010), there were no gender differences found concerning the tendency of utilizing e-learning resources rather than attending face-to-face lectures [33]. Gammie et al. (2003) also brought some information about the background of the problem, exploring gender dissimilarities across numerous performance processes both before and after enrolling into an Accounting and Finance degree, delineating that female students outperformed their male colleagues in the first year, however no gender inconsistencies were identified in any of the final year modules [34]. Taylor (2013) concluded that gender does not impact accounting students' ethical sensitivity [35], however Callaghan and Papgeorgiou (2015) revealed that female students are more responsible than male students, females being more hardworking, conscientious, diligent and, as a result, outperforming males [36]. Likewise, Roos (2009) showed that women outclass men in the entry requirements and examinations for accountancy bodies, such as the Chartered Institute of Management Accountants' (CIMA) professional qualification examinations [37].

Issues related to gender in the sustainable development of the accounting profession were investigated in many accounting research works. Thus, Kirkham and Loft (1993) analyzed how gendered discourses were displayed by the early professional accountancy bodies, in order to find and legitimize the dissimilarities between, not only accountants and women per se, but between accountants and men in correlated jobs (i.e., clerks and bookkeepers), concluding that by 1930, the "Professional Accountant" had come to be established, partly, as someone that is "not a clerk or a bookkeeper" respectively, partly, as someone that is "not a woman" [38]. Anderson et al. (1994) appraised whether family structure, gender, and physiognomy are perceived to contribute to future career success in accounting [39]. Results showed that accountants and auditors who were labelled as "female", "married with children", and "poor in physical appearance" were usually alleged as less likely to thrive. Fasci and Valdez (1998) inspected and paralleled the performance of male-owned and female-owned accounting practices and statistically investigated whether a gender-based differential existed between analyzed accounting practices [40]; the results indicated that while business ownership may, perchance, provide women a feasible opportunity for achieving career success, gender appeared to negatively sway on their firms' earnings. Radtke (2000) investigated whether gender affects ethically sensitive decisions of accountants [41]. The results obtained by computing data from 51 practicing accountants from both public and private industry suggested that ethical decisions of female and male accountants do not differ significantly. Whiting and Wright (2001) examined gender inequity and discrimination in the New Zeeland accounting profession and found that females held lower job status and were remunerated less than their male counterparts [42].

Some early studies, as well as current work focus on gender differences leadership styles. Burke and Collins (2001) found that leadership styles of female accountants diverge from the leadership styles reported by male accountants [43], women being more likely to use transformational leadership than men. Correspondingly, female accountants reported somewhat higher perceived effectiveness on coaching and developing, as well as on communication, and/or management skills. An investigation related to tax accountants' gender and their work attitudes was conducted by Luttman et al. (2003), their results demonstrating that male and female tax accountants contrasted on aspects regarding job satisfaction, organizational commitment, and role conflict [44]. Women were more content with their jobs, more dedicated to the organizations, and testified less role conflict than men did.

The effects of age and gender of Professional Accountants on the level of job satisfaction, as well as the examination of whether they compel to alterations in the acuities of work-related attributes (i.e., advancement opportunities and relation with superiors) were explored by Moyes et al. (2006) [45]. Results pointed out that job fulfilment, behavior of colleagues and managers, employee relations with co-workers, promotion and advancement opportunities, with respect to gender discrimination are 
correlated to age and gender, but the amount of compensation, provided fringe benefits and required amount of workload are not significant with age and gender. Men's attitude concerning the admission of women into professional bodies in the formative years of the accounting profession in Australia was investigated by Cooper (2007), who proved that same as in UK, all Australian accounting bodies initially banned female membership; however, accountants in public practice succeeded in resisting female membership longer than commercial or private accountants [46]. Dambrin and Lambert (2008) provided a qualitative approach of the difficulties of managing career progression, particularly in relation to motherhood, in case of women accountants working for the Big Four in France [47]. Conversely, Komori (2008) argued that Japanese women have managed to change the accounting practice by applying a feminine approach to their work [48]. Gammie and Whiting (2013) examined whether the gendered work practices of professional accountancy companies influence female choice to look for alternative employment [49]. The study suggested that the main motive women leave accountancy firms is to seek more motivating and challenging work, as opposed to gaining more flexibility in their lives. Seminal contributions have been made by Carmona and Ezzamel (2016), who argued that the construction of gendered identity in the workplace concerns "how individuals perform gender in an imaginatively produced space for the purposes of control and domination" [50]. Recent research suggests that gender discrimination is an issue that remains to be addressed, as Tiron-Tudor and Faragalla (2018) examined gender issues related to the career plans followed in the accounting profession. They emphasized that gender discrimination is undeniably present through glass-ceiling phenomenon, double standard, motherhood, respectively all the consequences that come with all these, conducting to a lack of visibility [14].

Matters of gender diversity in correlation to business performance were examined by Gallego-Alvarez et al. (2010), who focused on the incidence and effect of female shareholders, directors and top managers by evaluating their influence on several accounting ratios, market value and technical efficiency [51]. Results appear to be inconsistent with prior research, showing that organizations with higher levels of gender diversity do not perceptibly outperform other organizations with lower levels, in terms of several market and accounting measures, the main conclusion being that gender diversity may not sway corporate performance. Similarly, Khalife and Chalouhi (2013) conducted a comparative study among Lebanese male and female-owned small firms, their findings presenting strong evidence that firms owned by women generated lower gross revenues than firms owned by their counterparts [52]. Yet, no substantial dissimilarities were encountered between male and female-owned companies as regards incomes.

Studying gender differences in financial reporting decision-making, Rose (2007) showed that Danish boards are yet in a significant proportion dominated by men, and-in opposition to several other reports-did not find any major connection amid company performance (as measured by Tobin's Q) and female board representation [53]. Barua et al. (2010) examined the interconnection between the Chief Financial Officer's (CFO) gender and the adequacy of accruals, showing that organizations with female CFOs have lower performance-matched absolute discretionary accruals and lower absolute accrual estimation errors [54]. By the same token, Peni and Vahamaa (2010) examined the association between earnings management and the top management's gender [55]. Results provided considerable evidence to advocate that economic entities with female CFOs are associated with income-decreasing discretionary accruals, thereby suggesting that women are following more conservative strategies as regards earnings management. In the same context, Francis et al. (2015) probed the effect of CFO gender on decision-making concerning corporate financial reporting and established that women are more conservative in their financial reporting. Moreover, the results showed that the risk-aversion of female CFOs is linked to less equity-based compensation, lower company risk, higher tangibility level, and inferior dividend payout level [56]. Furthermore, the research provided sturdy evidence in respect of the fact that female CFOs are more risk-averse than male CFOs, which induces them to embrace conformist, conservative financial reporting policies. 
Regarding the ethical and sustainable dimension of accounting judgment, several studies found evidence for a lesser ethical and sustainability-driven attitude of males, pointing out that companies with more women in senior positions suffer less in times of economic downturn, which puts forward that gender diversity plays its part, also contributing to sustainability [57-59].

Odar et al. (2017) examined Slovenian accountants' perceptions of ethical judgment in accounting services in a non-regulated market context and detected no statistically substantial correlation between the acceptability level of ethically sensitive scenarios and gender, age, and educational level [60]. In contrast, Conroy et al. (2010) reconnoitered ethical behavior of US accounting practitioners using a multiple segment factorial vignette approach and established that the most robust predictor of ethical attitude was age [61].

The disparity between men and women in accounting profession was also observed in the academic field, where, despite the fact that the number of women has gradually increased, senior academic positions are still reigned by men, as evidenced by Siboni et al. (2016), Galizzi \& Siboni (2016), Baldarelli et al. (2016) [22,62,63].

As Odar et al. (2017) pointed out, studies of business ethics in accounting have demonstrated that age and gender play a primordial role in predicting individuals' ethical, sustainable attitudes [60]. On the same topic, the majority of prior research postulated age and gender to be the most robust predictors of accountants' ethical behaviour [61,64,65], while others (like Barnett et al., 1994 and Radtke, 2000) found different results that showed no significant correlation between age, gender and ethical judgment $[41,66]$.

However, we considered to be of interest to investigate the influences exerted by age and gender differences on accounting judgments in the case of Romanian Professional Accountants.

The study was undertaken solely in Romania, first of all, because of logistical and organizational reasons; in order to send the questionnaire for completion it was necessary to create a database with the e-mail addresses of the members of the representative accounting professional body, the Body of Expert and Licensed Accountants of Romania (BELAR), data which was obtained from the official Chart of Accountants published in the Official Romanian Gazette. It was also necessary to obtain the official agreement of the Branch Management when the process of submitting the questionnaire started, due to GDPR motives.

In addition, in the current context of implementing the standards and requirements of sustainable development (i.e., SDGs) in emerging countries, we consider the study conducted in Romania is of interest in order to achieve a more realistic assessment of the evolution of the accounting profession, as well as to tackle specific aspects regarding gender (in)equality in emerging countries (in this context, Romania). We consider gender inequality might be a grander issue in emerging markets than elsewhere in the modern world due to three main reasons: failure in public policy regarding the mitigation of the distributive consequences of accelerated growth in emerging markets that, in the last three decades has outshined growth in the rest of the world; the major role played by the informal sector in emerging markets, a sector in which a great number of economically active women earn casual and irregular wages from unreliable and often transitory employment; the disruption of traditional familial structures and support systems caused by massive urbanization on an unprecedented scale and at an unparalleled pace.

In this regard, based on the discussion above and taking into account the objectives of the study, the following research hypotheses were formulated:

Hypothesis 1 (H1). Professional Accountants' age and gender influence the fundamentals of accounting judgments.

Hypothesis 2 (H2). Professional Accountants' age and gender influence the theoretical framework of professional accounting judgment and there are significant differences between men and women related to the exercise of accounting judgments and estimates. 
Hypothesis 3 (H3). There are significant differences between men and women concerning the exercise of accounting judgments by consulting the entity's management.

Hypothesis 4 (H4). There are significant differences between men and women skepticism regarding the nature of economic events and transactions that require an accounting judgment.

Hypothesis 5 (H5). There are significant differences between men and women concerning the interest pursued by Professional Accountants in choosing and applying accounting policies.

Hypothesis 6 (H6). There are no significant differences between men and women opinion regarding the hierarchy of the most important features of an adequate professional accounting judgment.

Hypothesis 7 (H7). There are no significant differences between men and women opinion regarding the hierarchy of the most important accounting issues that requires an adequate professional judgment.

\section{Materials and Methods}

\subsection{Collecting Data}

Our study aimed to investigate the Romanian Professional Accountants' opinion on accounting judgments and sustainable decision-making, in order to assess eventual dissimilarities in their reasoning in correlation with their gender and/or age. The quantitative research was based on a survey conducted among Romanian Professional Accountants, members of by the Body of Expert and Licensed Accountants of Romania (BELAR), so as to meet the research objectives and validate the seven hypotheses that were formulated.

BELAR is a public utility and autonomous legal entity, which includes Romanian chartered certified accountants (expert accountants) and licensed accountants, as well as commercial accountancy firms and accountancy companies under the conditions laid down by law. BELAR is a member of the International Federation of Accountants (IFAC) and currently has approximately 45,000 members, of which about 35,000 active members-individual Professional Accountants and Accounting Firms.

Hence, the data and information needed for the research were collected using an online questionnaire sent to the professionals in the form of a link via e-mail (Appendix A), using all valid e-mail addresses found in the Chart of Accountants published in the Official Romanian Gazette by the BELAR. The method is efficient by offering many advantages such as: medium to high flexibility in data collection, high degree of convenience for the respondent and low costs of data collection, as evidenced by Hair et al. (2016) [67].

Nonetheless, the major inconveniences or problems encountered were the following: invalid e-mail addresses (implying a smaller number of respondents and, consequently, a relatively low response rate), higher reluctance of some accounting professionals to answer to some questions, lack of interest in completing questionnaire sections, receiving negative feedback regarding the willingness to answer questions, obtaining negative feedback (or no feedback at all), from the perspective of not understanding the purpose and/or the relevance of completing such a questionnaire.

However, these are inherent issues of any qualitative research based on investigation. Yet, the interest shown in the investigated subject and the request received from several accounting professionals to provide them partial or complete research results were the engines of our motivation to conduct this extensive research, in order to draw some essential conclusions regarding the evolution of the accounting profession in Romania concerning current perceptions on professional accounting judgment and on sustainable decisions, as well as on gender (in)equality.

Henceforth, the sample population targeted Romanian Professional Accountants, members of BELAR, being identified in the databases of the Chart of Accountants. The sampling base was established by extracting a random sample from the reference population and drawing up a cross-list 
of 2800 Professional Accountants. The questionnaire was distributed in the form of a link by e-mail to the companies in the cross-list.

Henceforward, the research method used in the quantitative study was a survey by sampling, using the questionnaire as the data collection tool. A total of 2800 questionnaires were applied, out of which 587 questionnaires were received, obtaining a response rate of $21 \% .531$ valid responses were obtained and, subsequently, processed using statistical methods and tests.

In some of the analyses, especially in independent sample tests, we eliminated non-responses listwise to present the most relevant data. That means that in the case of questions using the Likert 5-level ordinal scale, in case a non-response was recorded to one item, we did not consider that respondents answered to all items in the scale. Consequently, in some tables the number of responses is significantly smaller compared to the total sample.

The questionnaire was developed on three levels and contained mostly closed questions, measured with nominal and ordinal scales, and a few open questions. All 43 questions reflected general data and information about the respondent, questions that aimed at the Professional Accountants' opinion on the main factors influencing the exercise of adequate accounting judgment, the theoretical framework of professional accounting judgment, the interest pursued by Professional Accountants in terms of accounting policies and sustainable decisions, the main characteristics of accounting judgments, deadline issues, customer satisfaction, managers' expectations and professional reasoning, and, finally, inquiries regarding personality traits such as optimism, self-confidence, propensity towards risk, creativity, etc.

\subsection{Data Analysis}

Collected data that was obtained from respondents were processed and analyzed using SPSS Statistics package, using the frequency and contingency tables and the Student's $t$-test.

A 5-level ordinal scale (Likert's scale) was used to construct the most questions with closed answers, respectively to measure the variables of the proposed model [68], while Cronbach's Alpha test was performed for internal correlations, as a measure of internal consistency, with the intention of assessing how closely related a set of items are as a group. This regulates the internal consistency or average correlation of items in a survey instrument with the purpose of measuring its reliability [69]. The data analysis was based on the Principal Component Analysis, in order to "extract the important information and represent it as a set of new orthogonal variables and to display the pattern of similarity of the observations and of the variables" [70]. Pearson's Linear Correlation Method (bivariate correlations) was employed for the verification and confirmation of the hypotheses [71].

\section{Results}

As we found in the analysis of the local specialty literature regarding the stereotypes in the accounting profession, the years of communism marked their defining features. Thus, as statistics at the national level indicate, the share of women among the members of the representative professional bodies (Body of Expert and Licensed Accountants of Romania-BELAR and Chamber of Financial Auditors of Romania-CFAR) has increased from one year to another [72-75].

Nowadays, this profession in Romania is perceived as one that requires a lot of patience, meticulousness, involving repetitive, static activities and is not infrequently understood as an extremely routine profession such as a woman's housework. These considerations determine that in the accounting profession, in an emerging country like Romania, more and more women want practice in this field.

Using the demographic database of the BELAR, our statistics showed that the percentage of female Professional Accountants involved in the accounting profession exceeds $72 \%$. Results are in line with Istrate's (2012) work that found approximately $70 \%$ women accountants engaged in the BELAR and $66 \%$ in the CFAR [72]. Previous studies conducted on Romanian accounting profession shown that the higher number of female accountants can be explained either by the numerous years in which Romania was under the communist regime, either through the fact that the accounting field is 
perceived as a feminine one [72-75]. This would also explain the higher number of female graduates in the accounting field, as well as the higher number of women enrolling in the accounting profession after graduation.

In our survey, out of the 531 Professional Accountants who responded to the questionnaire, 124 are men and 397 are women. It can be presumed that the much higher response rate obtained from women shows that the interest in understanding the issues that influence accounting judgments, estimates and accounting decisions is grander for female accountants than for male accountants.

Statistics made using the information disclosed publicly on the website of Romanian accounting professional body (BELAR) on branches board members showed that women professionals engaged in the management of the accounting profession represent $62.84 \%$, while at the level of some branches the percentage of women in the total members is approaching more and more significant numbers (for example, at the level of the Constanta branch, the share is $85 \%$ of the total members, according to Ticoi, 2019 [76]).

Therefore, the gender distribution of valid answers does not surprise us, considering the statistical data at national level regarding the higher percentage of professional women accountants than men among the members of representative professional organizations in Romania (Body of Expert and Licensed Accountants of Romania-BELAR and Chamber of Financial Auditors of Romania-CFAR).

In terms of investigating the respondents' professional experience, over $80 \%$ of the Professional Accountants specified they had more than 10 years of experience in accounting practice, while only $1 \%$ stated they did not have any kind of practical experience in accounting.

The distribution of responses according to the professional experience of the respondents can be depicted in the table below (Table 1):

Table 1. Accountants' professional experience.

\begin{tabular}{cccc}
\hline \multicolumn{4}{c}{ What is Your Practical Experience in Accounting? } \\
\hline & Frequency & Valid Percent & Cumulative Percent \\
\hline no experience & 12 & 2.3 & 2.3 \\
under 1 year & 11 & 3.1 & 4.3 \\
between 1 and 5 years & 24 & 4.5 & 8.9 \\
between 5 and 10 years & 58 & 10.9 & 19.8 \\
over 10 years & 426 & 80.2 & 100.0 \\
Total & 531 & 100.0 & \\
\hline
\end{tabular}

Source: Own elaboration.

As can be seen from the chart below (Figure 1), most of respondents are over 35 years. The distribution of responses according to the age of the Professional Accountants showed that they were honest in statements about their age and experience in accounting, since between the respondents' age and professional experience there is a direct correlation.

Groff-Zaman (2015) provided empirical evidence on the positive association between professional qualification and accounting competences related to the quality of rendered services to customers [77]. Thus, we considered relevant to examine the type of activities offered by Professional Accountants to their customers and to analyze the way they organize and manage they activities or business (Table 2). Over $38 \%$ of respondents said they were employed in an entity, and from this employee position they are acting as Professional Accountants, tasks and responsibilities in the activity of Professional Accountant being provided in the job description of the employee in the entity in which he or she is employed. More than 25\% of the Professional Accountants have declared that they provide also accounting services that are complementary to the accounting field in their own private offices as legal authorized entities with employees. 


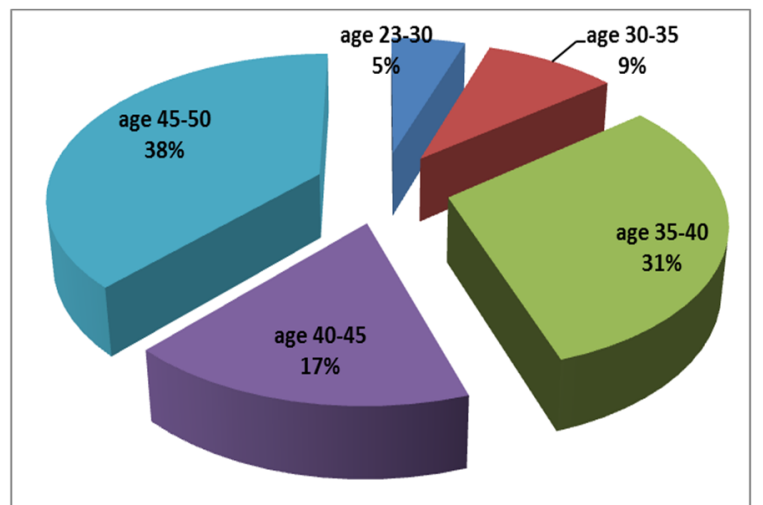

Figure 1. Professional Accountants' age distribution. Source: Own elaboration.

Table 2. Professional Accountants' type of activities.

\begin{tabular}{lccc}
\hline \multicolumn{3}{c}{ Which is the Form of Organization of the Activity for the Accounting Services Rendered by You? } \\
\hline & Frequency & Valid Percent & Cumulative Percent \\
\hline Accountant as authorized person without employees & 109 & 20.5 & 20.5 \\
Accountant as authorized person with employees & 75 & 14.1 & 34.7 \\
Legal authorized entity without employees & 7 & 1.3 & 36.0 \\
Legal authorized entity with employees & 137 & 25.8 & 61.8 \\
Employee & 203 & 38.2 & 100.0 \\
Total & 531 & 100.0 & \\
\hline
\end{tabular}

Source: Own elaboration.

We questioned the Professional Accountants about the aspects they consider that influence the exercise of a Professional Accountant's judgment when choosing an accounting treatment for economic events and transactions. The answers to items and features of professional judgment were given on a Likert scale, where 1 represented "total disagreement" and 5 "total agreement". As presented in Figure 2, most answers regarding the accuracy, adequacy and correctness of the accountants' professional judgment have a higher average response on the scale. This suggests that all aspects studied are considered as relevant by professionals.

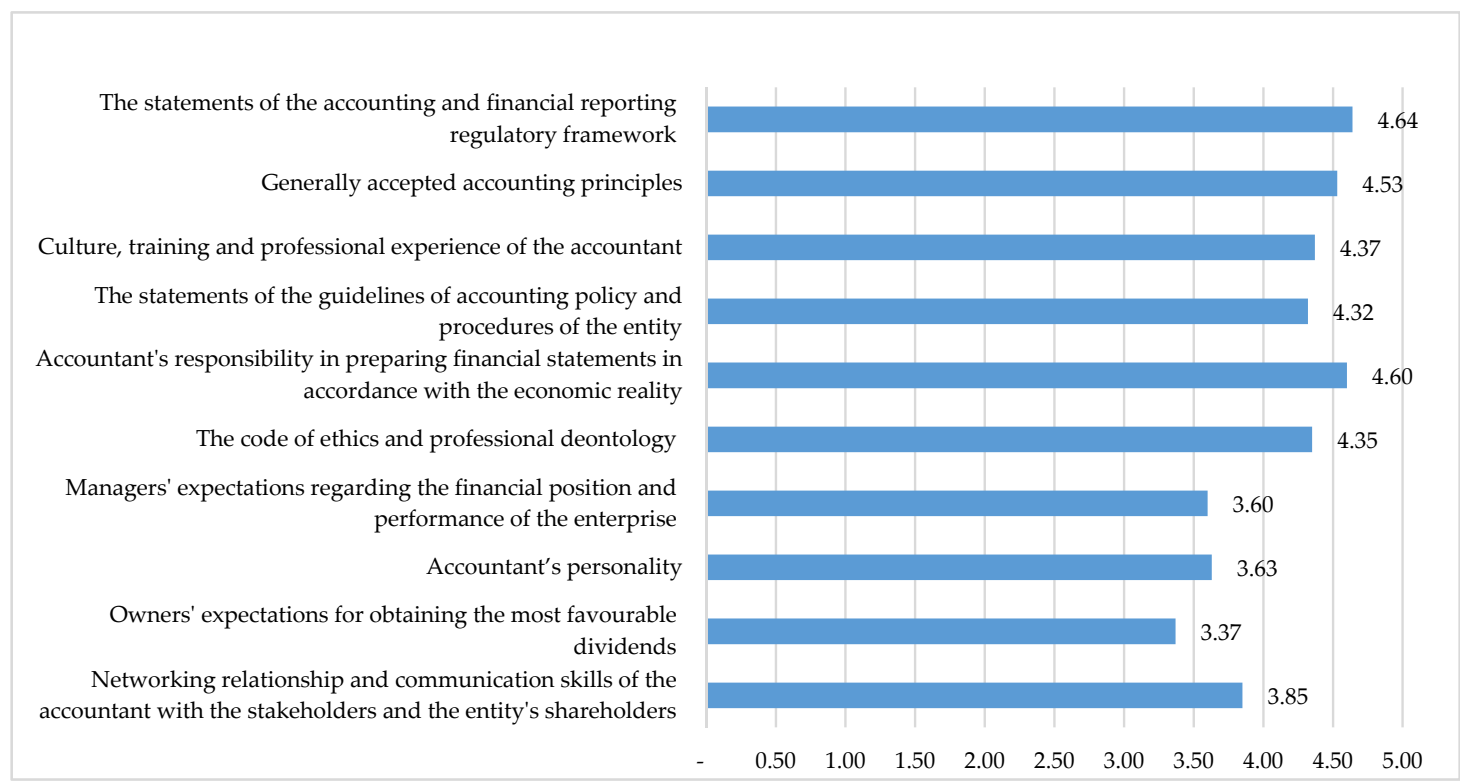

Figure 2. Factors that influence the professional accounting judgment. Source: Own elaboration. 
Respondents considered, to the greatest extent, that the exercise of professional accounting judgment is influenced by the accountability of the accountant in preparing financial statements that are in line with the economic reality and the sustainability matters, as well as with the provisions of the accounting standards or regulations and financial reporting framework. In the lowest proportion, Romanian Professional Accountants deliberate that their judgment is swayed by the owners' expectations for obtaining the most favorable dividends. Most of the interviewed accountants fully agree that the main focus pursued by Professional Accountants in choosing and applying accounting policies lies in respecting the current accounting regulatory framework and other legal provisions $(70.79 \%)$ and in complying with the ethical principles and professional deontology $(53.01 \%)$, while, in the lowest proportion, in minimizing the accounting result for fiscal optimization $(6.03 \%)$. $64 \%$ of the interviewed accountants fully agree that Professional Accountants' reasoning can only be applied after all evidence on the economic or financial event has been collected and analyzed, whereas $49 \%$ of them agree that their judgment may be exercised merely against the backdrop of the existence of a theoretical regulatory framework, accounting principles, standards, regulations and guidelines. Nearly half of the respondents ( $48 \%)$ settle that professional accounting judgment can only be exercised following a proper logical reasoning approach, and about two-thirds of the respondents fully concur that accounting judgments should be properly documented. Nearly half of the subjects (47\%) agree that the choice of accounting treatment as a result of the exercise of professional judgment shall be achieved by consulting the entity's management. More than half of respondents $(52 \%)$ acknowledge the assertion that a qualitative, adequate professional reasoning influences the relevance of accounting information, though less than half of those questioned (48\%) embrace the assertion that Professional Accountants should always question economic events and transactions in order to exert an adequate reasoning. In this context, Professional Accountants considered that an adequate professional accounting judgment is best distinguished by the following features: "logical, consistent and substantiated", accompanied by "independent without being influenced by managers" and with the slightest proportion being characterized by "flexibility". To the open question "What are the first words that come to mind when you hear about professional accounting judgment?" The most common words used by respondents, were: fairness, logic, experience and professionalism or balance.

The Professional Accountants were invited to appreciate the importance of making an adequate professional accounting judgment to assign the accounting treatment for the following accounting issues and sustainable decisions: estimates and changes in estimates and accounting policies; impairment of assets; revaluation of assets; contingent assets and liabilities; assessing risks and uncertainties in resource management; evaluation of goodwill; evaluation of intellectual property rights; assessment of intellectual capital and other non-material investments; assessing borrowing costs; evaluating the costs of restructuring the activities, in a sustainable way; assessment of decommissioning costs of noncurrent assets; evaluation of development and innovation costs; estimates of employee benefits; estimates on deferred taxes and valuation at fair value. A 5-level ordinal scale (Likert's scale) was used, as well, where 1 represented "very important" and 5 "not at all important". The adequate professional accounting judgment is appreciated by respondents to be of the utmost importance (44.83\%), in relation to the allocation of the accounting treatment for estimates and changes in estimates and accounting policies. The same adequate professional accounting judgment is considered to be very important $(48.23 \%)$ with the regard to the assignment of the accounting treatment for measurement at fair value.

\section{Discussion}

Further on in our study we tested the first working hypothesis:

Hypothesis 1 (H1). Professional Accountants' age and gender influence the fundamentals of accounting judgments. 
Using the independent sample T-test (Tables 3 and 4), we found that there are significant differences between male accountants and female accountants in three aspects, considered important in influencing the professional accounting judgments: the fact that an adequate professional judgment depends on the "the statements of the accounting and financial reporting regulations framework", "managers" expectations regarding the financial position and performance of the enterprise" and the "code of ethics". In all cases women have a higher mean of responses than men: 4.69 compared to 4.49 for men when considering the legal framework, as well as the manager's expectation, 3.65 for women compared to 3.41 for men, when referring to manager's expectations, respectively 4.39 for women compared to 4.20 for men, regarding the importance of code of ethics.

Table 3. Statistics on gender influences on professional accounting judgment.

\begin{tabular}{|c|c|c|c|c|c|}
\hline Influences on the Professional Accounting Judgment & Gender & $\mathbf{N}$ & Mean & $\begin{array}{l}\text { Std. } \\
\text { Dev. }\end{array}$ & $\begin{array}{l}\text { Std. Error } \\
\text { Mean }\end{array}$ \\
\hline $\begin{array}{l}\text { The statements of the accounting and financial reporting } \\
\text { regulatory framework }\end{array}$ & Male & 107 & 4.49 & 0.521 & 0.050 \\
\hline \multirow{2}{*}{ Generally accepted accounting principles } & Male & 107 & 4.49 & 0.650 & 0.063 \\
\hline & Female & 334 & 4.54 & 0.511 & 0.028 \\
\hline \multirow{2}{*}{$\begin{array}{l}\text { Managers' expectations regarding the financial position and } \\
\text { performance of the enterprise }\end{array}$} & Male & 107 & 3.41 & 1.098 & 0.106 \\
\hline & Female & 334 & 3.65 & 0.989 & 0.054 \\
\hline \multirow{2}{*}{$\begin{array}{l}\text { The provisions of the entity's manual of accounting policies } \\
\text { and procedures }\end{array}$} & Male & 107 & 4.22 & 0.604 & 0.058 \\
\hline & Female & 334 & 4.33 & 0.649 & 0.035 \\
\hline Accountant's professional experience, training, culture and knowledge & Female & 334 & 4.39 & 0.674 & 0.037 \\
\hline \multirow{2}{*}{ Code of ethics and professional deontology } & Male & 107 & 4.20 & 0.693 & 0.067 \\
\hline & Female & 334 & 4.39 & 0.674 & 0.037 \\
\hline \multirow{2}{*}{$\begin{array}{l}\text { Networking relationship and communication skills of the accountant } \\
\text { with the stakeholders and the entity's shareholders }\end{array}$} & Male & 107 & 3.70 & 0.838 & 0.081 \\
\hline & Female & 334 & 3.88 & 0.859 & 0.047 \\
\hline \multirow{2}{*}{$\begin{array}{l}\text { The accountability of the accountant in preparing financial statements } \\
\text { in line with the economic reality of transactions and events }\end{array}$} & Male & 107 & 4.55 & 0.570 & 0.055 \\
\hline & Female & 334 & 4.61 & 0.562 & 0.031 \\
\hline
\end{tabular}

Note: Important criteria related to the hypothesis have been bolded for clarity. Source: Own elaboration.

Table 4. T-test results: mean responses on gender influences on professional accounting judgment.

\begin{tabular}{|c|c|c|c|c|c|c|}
\hline \multirow[b]{2}{*}{ Influences on the Professional Accounting Judgment } & \multirow[b]{2}{*}{ Gender } & \multicolumn{5}{|c|}{ T-Test for Equality of Means } \\
\hline & & $\mathbf{T}$ & Df & $\begin{array}{c}\text { Sig. } \\
\text { (2-Tailed) }\end{array}$ & $\begin{array}{c}\text { Mean } \\
\text { Diff. }\end{array}$ & $\begin{array}{l}\text { Std. Error } \\
\text { Diff. }\end{array}$ \\
\hline \multirow{2}{*}{$\begin{array}{l}\text { The statements of the accounting and financial reporting } \\
\text { regulatory framework }\end{array}$} & Male & -3.645 & 439 & 0.000 & -0.200 & 0.055 \\
\hline & Female & -3.511 & 168.698 & 0.001 & -0.200 & 0.057 \\
\hline \multirow{2}{*}{ Generally accepted accounting principles } & Male & -0.870 & 439 & 0.385 & -0.053 & 0.061 \\
\hline & Female & -0.770 & 150.334 & 0.442 & -0.053 & 0.069 \\
\hline Owners' expectations for obtaining the most favorable dividends & Female & -0.765 & 178.989 & 0.445 & -0.097 & 0.127 \\
\hline \multirow{2}{*}{$\begin{array}{l}\text { Managers' expectations regarding the financial position and } \\
\text { performance of the enterprise }\end{array}$} & Male & -2.111 & 439 & 0.035 & -0.238 & 0.113 \\
\hline & Female & -2.001 & 164.722 & 0.047 & -0.238 & 0.119 \\
\hline \multirow{2}{*}{$\begin{array}{l}\text { The provisions of the entity's manual of accounting policies } \\
\text { and procedures }\end{array}$} & Male & -1.524 & 439 & 0.128 & -0.108 & 0.071 \\
\hline & Female & -1.582 & 190.642 & 0.115 & -0.108 & 0.068 \\
\hline
\end{tabular}


Table 4. Cont.

\begin{tabular}{|c|c|c|c|c|c|c|}
\hline \multirow[b]{2}{*}{ Influences on the Professional Accounting Judgment } & \multirow[b]{2}{*}{ Gender } & \multicolumn{5}{|c|}{ T-Test for Equality of Means } \\
\hline & & $\mathbf{T}$ & Df & $\begin{array}{l}\text { Sig. } \\
\text { (2-Tailed) }\end{array}$ & $\begin{array}{l}\text { Mean } \\
\text { Diff. }\end{array}$ & $\begin{array}{l}\text { Std. Error } \\
\text { Diff. }\end{array}$ \\
\hline \multirow{2}{*}{ Code of ethics and professional deontology } & Male & -2.559 & 439 & 0.011 & -0.193 & 0.075 \\
\hline & Female & -2.523 & 174.965 & 0.013 & -0.193 & 0.076 \\
\hline \multirow{2}{*}{$\begin{array}{l}\text { Networking relationship and communication skills of the accountant } \\
\text { with the stakeholders and the entity's shareholders }\end{array}$} & Male & -1.858 & 439 & 0.064 & -0.176 & 0.095 \\
\hline & Female & -1.882 & 182.871 & 0.061 & -0.176 & 0.094 \\
\hline \multirow{2}{*}{$\begin{array}{l}\text { The accountability of the accountant in preparing financial statements } \\
\text { in line with the economic reality of transactions and events }\end{array}$} & Male & -0.996 & 439 & 0.320 & -0.062 & 0.063 \\
\hline & Female & -0.988 & 176.785 & 0.324 & -0.062 & 0.063 \\
\hline
\end{tabular}

Note: Important criteria related to the hypothesis have been bolded for clarity. Source: Own elaboration.

It can be stated that female Professional Accountants are more inclined to strictly comply with accounting regulations and standards than their colleagues, male Professional Accountants, and also are more interested in following the principles of professional ethics in their activity of preparing the accounting figures and financial reports. Women accountants are more conformist and have a higher ethical behavior than men accountants. Also, women tend to be more interested in fulfilling managers' expectations regarding the financial position and performance of companies compared to their male colleagues.

However, it can be argued that female accountants are more willing to meet the managers' performance need for performance or are more open to respond positively to managers' performance expectations of the companies they run.

Taking into account our previous research conducted on professional accounting judgment [28], we have investigated if there are significant differences between male and female Professional Accountants related to the exercise of accounting judgments and the theoretical framework of accounting judgments, as well as the skepticism of accountants in analyzing the economic transactions and events that require an accounting judgment $(\mathrm{H} 2, \mathrm{H} 3$ and $\mathrm{H} 4)$.

Hypothesis 2 (H2). Professional Accountants' age and gender influence the theoretical framework of professional accounting judgment and there are significant differences between men and women related to the exercise of accounting judgments and estimates.

Hypothesis 3 (H3). There are significant differences between men and women concerning the exercise of accounting judgments by consulting the entity's management.

Hypothesis 4 (H4). There are significant differences between men and women skepticism regarding the nature of economic events and transactions that require an accounting judgment.

The process of developing judgments becomes more complex and more difficult, therefore it is crucial to have a framework to guide the accountant. Thus, we considered the KPMG Professional Judgment Framework (2011), one of the most reliable frameworks due to its complexity, utility and consistency [78]. This framework includes a mix of components such as mindset, consultation, knowledge and professional standards, influences and biases, reflection, and coaching.

The results of the statistical tests are summarized and presented below (Tables 5 and 6).

We found that there is only one significant difference between male and female Professional Accountants related to the exercise of accounting judgments, namely when referring to the consultation of the management of the entity for choosing the accounting treatment. In this case women are more "tolerant or inclusive" with a higher mean of response to this statement of 3.66 then men (3.42) (as per Table 5). Furthermore, we have not found any correlation between age and the theoretical framework of professional accounting judgment. Significant differences can be observed regarding the availability of women professionals to consult the entity's management in order to choose accounting options after an accounting judgment has been made on an event or transaction. 
Table 5. Group statistics on gender influences on the theoretical framework of professional accounting judgment.

\begin{tabular}{|c|c|c|c|c|c|}
\hline Theoretical Framework of Professional Accounting Judgment & Gender & $\mathbf{N}$ & Mean & $\begin{array}{l}\text { Std. } \\
\text { Dev. }\end{array}$ & $\begin{array}{l}\text { Std. Error } \\
\text { Mean }\end{array}$ \\
\hline \multirow{2}{*}{$\begin{array}{l}\text { The professional accounting judgment can be exercised only after all information } \\
\text { regarding the economic/financial event or transaction has been collected } \\
\text { and analyzed? }\end{array}$} & Male & 122 & 4.54 & 0.548 & 0.050 \\
\hline & Female & 390 & 4.61 & 0.614 & 0.031 \\
\hline \multirow{2}{*}{$\begin{array}{l}\text { The professional accounting judgment can be exercised only in the context of the } \\
\text { existence of a general conceptual accounting framework, accounting standards } \\
\text { or regulations and other accounting guides? }\end{array}$} & Male & 122 & 4.16 & 0.754 & 0.068 \\
\hline & Female & 390 & 4.24 & 0.776 & 0.039 \\
\hline \multirow{2}{*}{$\begin{array}{l}\text { The professional accounting judgment can be exercised only after a proper } \\
\text { logical judgment process has been conducted? }\end{array}$} & & 121 & 4.34 & 0.5 & 0.054 \\
\hline & Female & 385 & 4.31 & 0.776 & 0.040 \\
\hline \multirow{2}{*}{ Does the professional accounting judgment have to be properly documented? } & & & & 0.5 & 0.0 \\
\hline & & & & 0.632 & 0.032 \\
\hline \multirow{2}{*}{$\begin{array}{l}\text { Choosing an accounting treatment following the exercise of a professional } \\
\text { accounting judgment will be done by consulting the management of } \\
\text { the entity? }\end{array}$} & Male & 122 & 3.42 & 1.074 & 0.097 \\
\hline & Female & 389 & 3.66 & 0.997 & 0.051 \\
\hline \multirow{2}{*}{$\begin{array}{l}\text { Does an adequate and high quality professional accounting judgment influence } \\
\text { the relevance of financial-accounting information? }\end{array}$} & Male & 122 & 4.34 & 0.701 & 0.064 \\
\hline & Female & 391 & 4.44 & 0.755 & 0.038 \\
\hline \multirow{2}{*}{ Making professional judgments is a key skill of Professional Accountants? } & & & & 0.5 & 0.05 \\
\hline & Female & 388 & 4.56 & 0.551 & 0.028 \\
\hline \multirow{2}{*}{$\begin{array}{l}\text { Do accountants have to question economic events/transactions in order to make } \\
\text { an appropriate professional judgment? }\end{array}$} & $\mathrm{Ma}$ & 122 & 3.69 & 1.045 & 0.095 \\
\hline & Female & 388 & 3.58 & 1.067 & 0.054 \\
\hline
\end{tabular}

Note: Important criteria related to the hypothesis have been bolded for clarity. Source: Own elaboration.

Table 6. T-test results: mean responses on gender influences on the theoretical framework of professional accounting judgment.

\begin{tabular}{|c|c|c|c|c|c|c|}
\hline Theoretical Framework of Professional Accounting Judgment & Gender & $\mathbf{T}$ & Df & $\begin{array}{l}\text { Sig. } \\
\text { (2-Tailed) }\end{array}$ & $\begin{array}{l}\text { Mean } \\
\text { Diff. }\end{array}$ & $\begin{array}{l}\text { Std. Error } \\
\text { Diff. }\end{array}$ \\
\hline \multirow{2}{*}{$\begin{array}{l}\text { The professional accounting judgment can be exercised only after all } \\
\text { information regarding the economic/financial event or transaction has } \\
\text { been collected and analyzed? }\end{array}$} & Male & -1.115 & 510 & 0.266 & -0.069 & 0.062 \\
\hline & Female & -1.183 & 224.152 & 0.238 & -0.069 & 0.059 \\
\hline \multirow{2}{*}{$\begin{array}{l}\text { The professional accounting judgment can be exercised only in the } \\
\text { context of the existence of a general conceptual accounting framework, } \\
\text { accounting standards or regulations and other accounting guides? }\end{array}$} & Male & -0.900 & 510 & 0.369 & -0.072 & 0.080 \\
\hline & Female & -0.914 & 207.496 & 0.362 & -0.072 & 0.079 \\
\hline \multirow{2}{*}{$\begin{array}{l}\text { The professional accounting judgment can be exercised only after a } \\
\text { proper logical judgment process has been conducted? }\end{array}$} & Male & 0.320 & 504 & 0.749 & 0.025 & 0.077 \\
\hline & Female & 0.365 & 257.264 & 0.716 & 0.025 & 0.067 \\
\hline \multirow{2}{*}{$\begin{array}{l}\text { Does the professional accounting judgment have to be } \\
\text { properly documented? }\end{array}$} & Male & -1.009 & 506 & 0.313 & -0.064 & 0.063 \\
\hline & Female & -1.122 & 238.866 & 0.263 & -0.064 & 0.057 \\
\hline \multirow{2}{*}{$\begin{array}{l}\text { Choosing an accounting treatment following the exercise of a } \\
\text { professional accounting judgment will be done by consulting the } \\
\text { management of the entity? }\end{array}$} & Male & -2.278 & 509 & 0.023 & -0.240 & 0.105 \\
\hline & Female & -2.190 & 190.809 & 0.030 & -0.240 & 0.110 \\
\hline \multirow{2}{*}{$\begin{array}{l}\text { Does an adequate and high quality professional accounting judgment } \\
\text { influence the relevance of financial-accounting information? }\end{array}$} & Male & -1.242 & 511 & 0.215 & -0.096 & 0.077 \\
\hline & Female & -1.291 & 215.554 & 0.198 & -0.096 & 0.074 \\
\hline \multirow{2}{*}{$\begin{array}{l}\text { Making professional judgments is a key skill of } \\
\text { Professional Accountants? }\end{array}$} & Male & -1.706 & 507 & 0.089 & -0.099 & 0.058 \\
\hline & Female & -1.664 & 192.880 & 0.098 & -0.099 & 0.060 \\
\hline \multirow{2}{*}{$\begin{array}{l}\text { Do accountants have to question economic events/transactions in } \\
\text { order to make an appropriate professional judgment? }\end{array}$} & Male & 0.986 & 508 & 0.325 & 0.109 & 0.110 \\
\hline & Female & 0.996 & 206.365 & 0.320 & 0.109 & 0.109 \\
\hline
\end{tabular}

Note: Important criteria related to the hypothesis have been bolded for clarity. Source: Own elaboration.

Thus, we can assert that female Professional Accountants are more open to consult or collaborate with the entity's management than their male colleagues in terms of assigning an accounting treatment to an event after exercising the professional accounting judgment. This feature may also be interpreted as a tendency for female Professional Accountants to consult with the management to ensure that the allocated accounting treatment is consistent with management policy, as long as male Professional Accountants prove to be more independent in judgments and accounting options.

This attitude of female accountants may lead to even greater uncertainty in professional judgment and in sustainable accounting choices, showing a need for management to acknowledge that their choices, judgments, estimates and even decisions are correct and appropriate. In our view, this tendency 
of female accountants to look for management assurance in respect to choose an accounting option after judgments and estimates are made, deserves further and more in-depth investigation.

We have interpreted the obtained result as that women have a greater propensity to comply with the rules, in general, in our case with the accounting regulations or standards, and also the management policies. In addition, we presume that women accountants are less interested in "playing" with numbers or "juggling" with accounting options, as it has also already been demonstrated in a number of studies (i.e., Francis et al. [56]) that women are more risk-averse and more cautious than men [56].

If we go further with our analysis, we can postulate that women have a lesser inclination towards creative accounting practices, but it is only an assumption that needs further investigation.

In terms of the Professional Accountants' opinion on the theoretical framework of professional accounting judgment, men have proven to be more critical in their responses than women. Men also proved to be more skeptical about economic events and transactions that require professional accounting judgment, however differences between women and men have not proved to be significant. In the context of exercising an accounting judgment on an event, the fact that men are more skeptical than women, shows that they need more justification of the economic substance of transactions, by casting doubt on their component parts and by looking for more evidence to clarify the core of the economic substance. The attitude of professional skepticism, even if it is an essential feature of the auditing profession, in the case of Professional Accountants who investigate economic and financial events in order to assign a correct and appropriate accounting treatment, represents a high quality indicator of the professional accounting act.

Our further objective was to investigate the attitude of Professional Accountants in choosing options and accounting policies, respectively to analyze whether it varies according to gender. In this respect we have built $\mathrm{H} 5$ work hypothesis.

Hypothesis 5 (H5). There are significant differences between men and women concerning the interest pursued by Professional Accountants in choosing and applying accounting policies.

We performed a Principal Component Analysis and found that we actually have two components, one related to compliance to accounting standards or regulations, and the other one linked to improvements on entities' performance and their financial position (Table 7).

Table 7. Principal component analysis on Professional Accountants' interest in accounting options and policies.

\begin{tabular}{lcc}
\hline \multicolumn{1}{c}{$\begin{array}{c}\text { Professional Accountants' Interest in Choosing and Applying } \\
\text { Accounting Policies }\end{array}$} & \multicolumn{2}{c}{$\begin{array}{c}\text { Component } \\
\text { 2: Compliance }\end{array}$} \\
\hline $\begin{array}{l}\text { Compliance with the accounting and financial regulatory framework } \\
\text { Compliance with the principles of professional ethics and }\end{array}$ & 0.024 & 0.835 \\
deontology code & 0.093 & 0.835 \\
Maximizing the accounting result in order to improve the entity's & 0.812 & 0.072 \\
financial position and performance & 0.689 & -0.186 \\
Minimizing the accounting result for tax optimization purposes & 0.850 & 0.026 \\
Maintaining the financial position of the entity and its performance & 0.864 & -0.059 \\
\hline Satisfying the managers' interests to achieve the set goals & & \\
\hline
\end{tabular}

Extraction Method: Principal Component Analysis. (2 components extracted). Source: Own elaboration.

Based on these results we built two distinct variables, one measuring the importance given to compliance to accounting regulations or standards, and the second one related to the improvements on companies' performance, both based on the mean of responses. This allowed us to measure the differences between men and women regarding the importance given to these two scales.

Pearson's correlation coefficient was used in the correlation analysis in order to evaluate the cross-correlation of the variables. 
The results showed that there is no significant difference between men and women regarding the scale of conformity/compliance to the accounting framework, neither was recorded any significant difference for the scale of improving the performance of entities.

Hitherto, as it can be observed in Table 8, as the age of Professional Accountants rises, the degree of compliance with accounting regulations or standards increases, as well. This can be explained by the fact that with the upsurge of the professional experience, the level of maturity in choosing the options and the substantiation of the accounting policies growths as well. With the acquisition of professional knowledge and experience, Professional Accountants are more interested in respecting not only the accounting regulatory framework, but also the principles of professional ethics, lowering the interest of young accountants in impressing the management by knowing and managing accounting options. With the increase of age, professional integrity and ethics are more important than "playing" and "rolling the dice" regarding the accounting options.

Table 8. Correlations between accountants' age and the compliance propensity to accounting regulations and standards.

\begin{tabular}{|c|c|c|c|}
\hline \multicolumn{4}{|c|}{ Correlations } \\
\hline & & Age & Conformity \\
\hline \multirow{3}{*}{ Age } & $\begin{array}{l}\text { Pearson } \\
\text { Correlation }\end{array}$ & 1 & $0.116^{* *}$ \\
\hline & Sig. (2-tailed) & & 0.008 \\
\hline & $\mathrm{N}$ & 521 & 518 \\
\hline \multirow{3}{*}{ Conformity } & $\begin{array}{l}\text { Pearson } \\
\text { Correlation }\end{array}$ & $0.116^{* *}$ & 1 \\
\hline & Sig. (2-tailed) & 0.008 & \\
\hline & $\mathrm{N}$ & 518 & 522 \\
\hline
\end{tabular}

**. Correlation is significant at the 0.01 level (2-tailed). Source: Own elaboration.

For the verification of the hypotheses, Pearson's linear correlation method (bivariate correlations) was used:

We were interested in investigating the main features that an appropriate professional accounting judgment should have, and in this regard we have formulated the following working hypothesis:

Hypothesis 6 (H6). There are no significant differences between men and women opinion regarding the hierarchy of the most important features of an adequate professional accounting judgment.

As can be seen from the tables below (Tables 9 and 10), there is a significant gender variation in terms of "accurate, appropriate accounting judgment" (under the conditions that this relates to the fact that only the relevant information about an economic event is used). The results indicate that men accountants have a greater propensity to exercise accurate judgments based on relevant information about events or transactions than their female counterparts.

Further on we analyzed the answers to the question that investigates the importance of the exercise of an adequate professional accounting judgment in order to assign the accounting treatment for fifteen accounting issues that we considered to be more vulnerable in conjunction with the exercise of an accounting judgment. In the process of selecting the accounting issues vulnerable to the exercise of an appropriate accounting judgment, we have taken into account the higher degree of risk and uncertainty that a reasonable and reliable accounting estimate implies. 
Table 9. Statistics on gender variation regarding the main features of appropriate accounting judgment.

\begin{tabular}{|c|c|c|c|c|c|}
\hline Main Features of an Appropriate Accounting Judgment & Gender & $\mathbf{N}$ & Mean & $\begin{array}{l}\text { Std. } \\
\text { Dev. }\end{array}$ & $\begin{array}{l}\text { Std. Error } \\
\text { Mean }\end{array}$ \\
\hline \multirow{2}{*}{ Logic appropriate accounting judgment } & Male & 66 & 1.48 & 0.808 & 0.100 \\
\hline & Female & 167 & 1.51 & 0.950 & 0.073 \\
\hline \multirow{2}{*}{ Flexible appropriate accounting judgment } & Male & 66 & 2.3788 & 1.01928 & 0.12546 \\
\hline & Female & 167 & 2.3174 & 0.96374 & 0.07458 \\
\hline \multirow{2}{*}{$\begin{array}{l}\text { Accurate appropriate accounting judgment, using only the } \\
\text { relevant information }\end{array}$} & Male & 66 & 2.0606 & 1.00581 & 0.12381 \\
\hline & Female & 167 & 1.7186 & 0.82787 & 0.06406 \\
\hline \multirow{2}{*}{$\begin{array}{l}\text { Correct reasonable appropriate accounting judgment, without being } \\
\text { altered by errors }\end{array}$} & Male & 66 & 1.7273 & 0.88657 & 0.10913 \\
\hline & Female & 167 & 1.5210 & 0.81284 & 0.06290 \\
\hline \multirow{2}{*}{$\begin{array}{l}\text { Estimated reasonable appropriate accounting judgment, evaluating } \\
\text { probabilities of risks, uncertainties and ambiguities }\end{array}$} & Male & 66 & 2.1212 & 0.88605 & 0.10907 \\
\hline & Female & 167 & 2.0719 & 0.81823 & 0.06332 \\
\hline \multirow{2}{*}{$\begin{array}{l}\text { Focused, reasonable appropriate accounting judgment, determines the } \\
\text { sustainable decision following a choice between several options }\end{array}$} & Male & 66 & 2.3030 & 0.99181 & 0.12208 \\
\hline & Female & 167 & 2.2695 & 0.95965 & 0.07426 \\
\hline \multirow{2}{*}{$\begin{array}{l}\text { Unbiased and independent reasonable appropriate accounting } \\
\text { judgment, without being influenced by the will of managers }\end{array}$} & Male & 66 & 1.8788 & 1.10266 & 0.13573 \\
\hline & Female & 167 & 1.7485 & 1.03388 & 0.08000 \\
\hline \multirow{2}{*}{$\begin{array}{l}\text { Balanced, reasonable appropriate accounting judgment, harmonizing } \\
\text { the experience with knowledge, intuition, emotions, various pressures } \\
\text { from the internal and external environment. }\end{array}$} & Male & 66 & 2.2727 & 1.29550 & 0.15947 \\
\hline & Female & 167 & 1.9521 & 1.13969 & 0.08819 \\
\hline
\end{tabular}

Note: Important criteria related to the hypothesis have been bolded for clarity. Source: Own elaboration.

Table 10. T-test results on gender variation regarding the main features of appropriate accounting judgment.

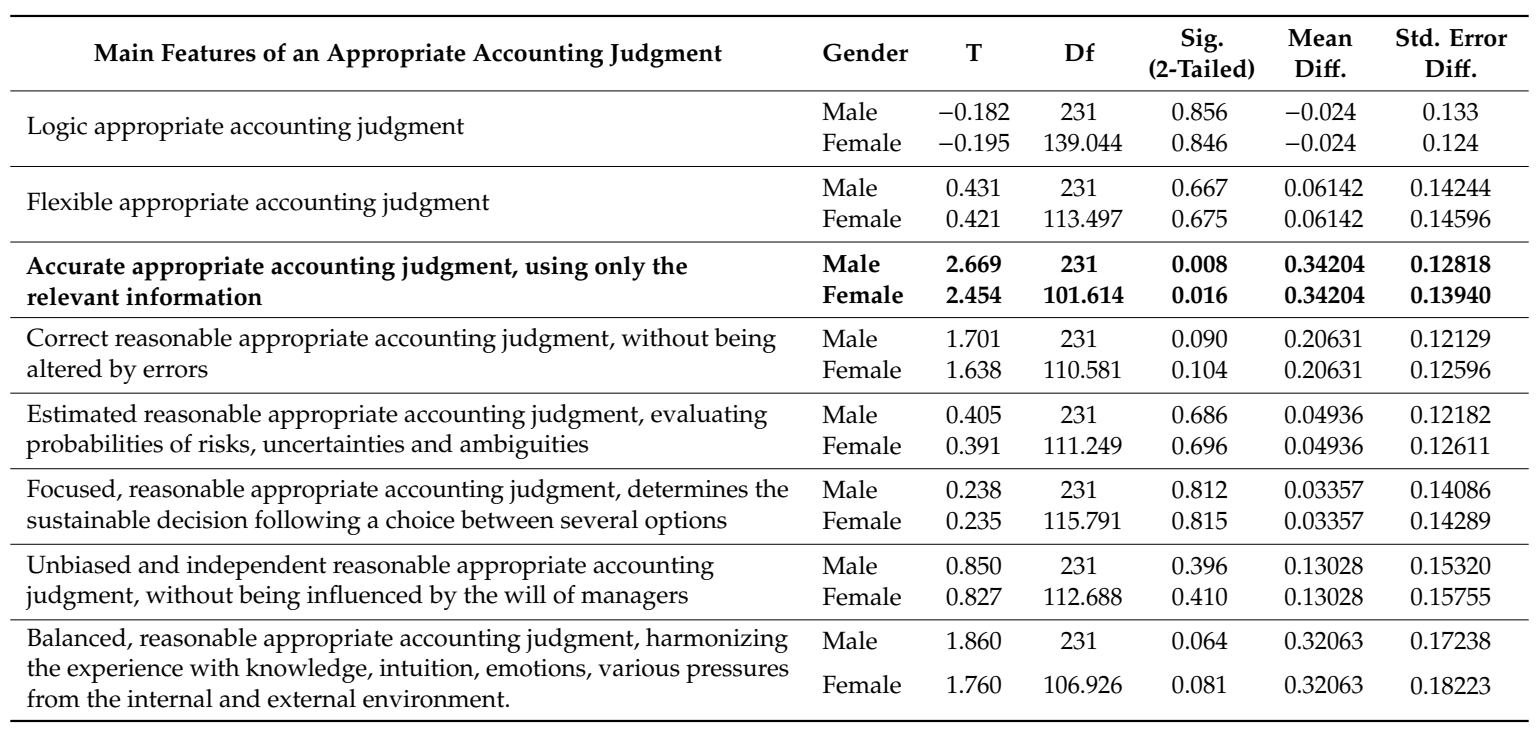

Note: Important criteria related to the hypothesis have been bolded for clarity. Source: Own elaboration.

Hypothesis 7 (H7). There are no significant differences between men and women opinion regarding the hierarchy of the most important accounting issues that requires an adequate professional judgment.

As can be seen in Tables 11 and 12, male accountants consider the accounting issues related to evaluation of goodwill and assessment of borrowing costs as more important than female accountants, from the point of view of exercising an adequate accounting judgment. As a result, men paying greater attention to these two accounting issues consider that the professional focus given to the exercise of accounting judgment in these two cases should be higher than in the other thirteen issues. In other words, they perceive goodwill and the borrowing costs, as two high-level accounting issues that require fair, sustainable, balanced and economically-based judgment, as well as reliable accounting estimates. 
Table 11. Statistics on gender variation regarding accountants' opinion on the adequate accounting judgment.

\begin{tabular}{|c|c|c|c|c|c|}
\hline Selected Accounting Issues & Gender & $\mathbf{N}$ & Mean & $\begin{array}{l}\text { Std. } \\
\text { Dev. }\end{array}$ & $\begin{array}{l}\text { Std. Error } \\
\text { Mean }\end{array}$ \\
\hline \multirow{2}{*}{ Estimates, changes in estimates and accounting policies } & Male & 105 & 1.90 & 0.950 & 0.093 \\
\hline & Female & 305 & 1.74 & 0.874 & 0.050 \\
\hline \multirow{2}{*}{ Impairment of assets } & Male & 105 & 1.98 & 0.888 & 0.087 \\
\hline & Female & 305 & 1.93 & 0.877 & 0.050 \\
\hline \multirow{2}{*}{ Revaluation of assets } & Male & 105 & 1.94 & 0.795 & 0.078 \\
\hline & Female & 305 & 1.88 & 0.916 & 0.052 \\
\hline \multirow{2}{*}{ Contingent assets and liabilities } & Male & 105 & 2.01 & 0.838 & 0.082 \\
\hline & Female & 305 & 1.97 & 0.886 & 0.051 \\
\hline \multirow{2}{*}{ Assessing risks and uncertainties in resource management } & Male & 105 & 1.93 & 0.902 & 0.088 \\
\hline & Female & 305 & 1.81 & 0.885 & 0.051 \\
\hline \multirow{2}{*}{ Evaluation of goodwill } & Male & 105 & 2.41 & 0.937 & 0.091 \\
\hline & Female & 305 & 2.18 & 0.928 & 0.053 \\
\hline \multirow{2}{*}{ Evaluation of intellectual property rights } & Male & 105 & 2.41 & 0.948 & 0.092 \\
\hline & Female & 305 & 2.32 & 0.968 & 0.055 \\
\hline \multirow{2}{*}{ Assessment of intellectual capital and other non-material investments } & Male & 105 & 2.31 & 0.954 & 0.093 \\
\hline & Female & 305 & 2.27 & 0.906 & 0.052 \\
\hline \multirow{2}{*}{ Assessment of borrowing costs } & Male & 105 & 2.03 & 0.965 & 0.094 \\
\hline & Female & 305 & 1.77 & 0.844 & 0.048 \\
\hline \multirow{2}{*}{ Evaluating the costs of restructuring the activities, in a sustainable way } & Male & 105 & 2.04 & 0.898 & 0.088 \\
\hline & Female & 305 & 1.87 & 0.800 & 0.046 \\
\hline \multirow{2}{*}{ Assessment of decommissioning costs of fixed assets } & Male & 105 & 2.28 & 0.935 & 0.091 \\
\hline & Female & 305 & 2.12 & 0.884 & 0.051 \\
\hline \multirow{2}{*}{ Evaluation of development and innovation costs } & Male & 105 & 2.08 & 0.817 & 0.080 \\
\hline & Female & 305 & 2.00 & 0.898 & 0.051 \\
\hline \multirow{2}{*}{ Estimates of employee benefits } & Male & 105 & 2.07 & 0.835 & 0.081 \\
\hline & Female & 305 & 2.05 & 0.882 & 0.050 \\
\hline \multirow{2}{*}{ Estimates on deferred taxes } & Male & 105 & 2.12 & 0.895 & 0.087 \\
\hline & Female & 305 & 2.04 & 0.924 & 0.053 \\
\hline \multirow{2}{*}{ Valuation at fair value } & Male & 105 & 1.76 & 0.915 & 0.089 \\
\hline & Female & 305 & 1.65 & 0.823 & 0.047 \\
\hline
\end{tabular}

Note: Important criteria related to the hypothesis have been bolded for clarity. Source: Own elaboration.

Table 12. T-test results on gender variation regarding accountants' opinion on the adequate accounting judgment.

\begin{tabular}{|c|c|c|c|c|c|c|}
\hline Accounting Issues & Gender & $\mathbf{T}$ & Df & $\begin{array}{c}\text { Sig. } \\
\text { (2-Tailed) }\end{array}$ & $\begin{array}{c}\text { Mean } \\
\text { Diff. }\end{array}$ & $\begin{array}{l}\text { Std. Error } \\
\text { Diff. }\end{array}$ \\
\hline Estimates, changes in estimates and accounting policies & Male & 1.493 & 408 & 0.136 & 0.151 & 0.101 \\
\hline \multirow{2}{*}{ Impairment of assets } & Male & 0.501 & 408 & 0.617 & 0.050 & 0.100 \\
\hline & Female & 0.497 & 178.636 & 0.619 & 0.050 & 0.100 \\
\hline Revaluation of assets & Male & 0.672 & 408 & 0.502 & 0.067 & 0.100 \\
\hline \multirow{2}{*}{ Contingent assets and liabilities } & Male & 0.395 & 408 & 0.693 & 0.039 & 0.099 \\
\hline & Female & 0.406 & 189.915 & 0.685 & 0.039 & 0.096 \\
\hline \multirow{2}{*}{ Assessing risks and uncertainties in resource management } & Male & 1.194 & 408 & 0.233 & 0.120 & 0.101 \\
\hline & Female & 1.184 & 177.831 & 0.238 & 0.120 & 0.102 \\
\hline Evaluation of goodwill & Male & 2.146 & 408 & 0.032 & 0.226 & 0.105 \\
\hline \multirow{2}{*}{ Assessment of intellectual capital and other non-material investments } & Male & 0.469 & 408 & 0.639 & 0.049 & 0.104 \\
\hline & Female & 0.457 & 172.910 & 0.648 & 0.049 & 0.107 \\
\hline
\end{tabular}


Table 12. Cont.

\begin{tabular}{|c|c|c|c|c|c|c|}
\hline Accounting Issues & Gender & $\mathbf{T}$ & Df & $\begin{array}{c}\text { Sig. } \\
\text { (2-Tailed) }\end{array}$ & $\begin{array}{c}\text { Mean } \\
\text { Diff. }\end{array}$ & $\begin{array}{c}\text { Std. Error } \\
\text { Diff. }\end{array}$ \\
\hline \multirow{2}{*}{ Assessment of borrowing costs } & Male & 2.636 & 408 & 0.009 & 0.261 & 0.099 \\
\hline & Female & 2.469 & 162.078 & 0.015 & 0.261 & 0.106 \\
\hline \multirow{2}{*}{ Evaluating the costs of restructuring the activities, in a sustainable way } & Male & 1.810 & 408 & 0.071 & 0.169 & 0.093 \\
\hline & Female & 1.711 & 164.472 & 0.089 & 0.169 & 0.099 \\
\hline \multirow{2}{*}{ Assessment of decommissioning costs of fixed assets } & Male & 1.557 & 408 & 0.120 & 0.158 & 0.102 \\
\hline & Female & 1.515 & 172.276 & 0.132 & 0.158 & 0.104 \\
\hline \multirow{2}{*}{ Evaluation of development and innovation costs } & Male & 0.734 & 408 & 0.463 & 0.073 & 0.099 \\
\hline & Female & 0.769 & 196.831 & 0.443 & 0.073 & 0.095 \\
\hline \multirow{2}{*}{ Estimates of employee benefits } & Male & 0.178 & 408 & 0.859 & 0.017 & 0.098 \\
\hline & Female & 0.182 & 189.556 & 0.855 & 0.017 & 0.096 \\
\hline \multirow{2}{*}{ Estimates on deferred taxes } & Male & 0.814 & 408 & 0.416 & 0.084 & 0.104 \\
\hline & Female & 0.827 & 185.678 & 0.409 & 0.084 & 0.102 \\
\hline \multirow{2}{*}{ Valuation at fair value } & Male & 1.210 & 408 & 0.227 & 0.116 & 0.096 \\
\hline & Female & 1.149 & 165.574 & 0.252 & 0.116 & 0.101 \\
\hline
\end{tabular}

Note: Important criteria related to the hypothesis have been bolded for clarity. Source: Own elaboration.

The results of our study provide supporting arguments for including the analysis of gender, age or of other variables in the discussion of authentic accounting reasoning, removing borders, eliminating gaps, and silencing gender issues in accounting decision-making, as well as on the in-depth examination of the generated classical image of traditional woman-man stereotypes in exercising accounting judgments.

In the current sensitive socio-economic global context, the questions that arise after obtaining the results and that will show the way to further refined analyses are: Is the accounting judgment more feminine or more masculine? Is the reasoning a young and enthusiastic one or rather a mature and cautious one?

\section{Conclusions}

The need to develop studies that investigate concrete issues about gender and accounting correlations is already recognized by the specialty literature.

We agree with Haynes (2008), who emphasized that there is a lack of studies to look more deeply into gender accounting and examine how feminist methodologies can improve the gender agenda in accounting [79]. Thus, by exploring several aspects of feminist methodology, power and politics, subjectivity and reflexivity, an argument for methodology was previously created.

We built our qualitative approach starting from Naranjo-Gil et al. (2010)'s statement, that researching issues that approach aspects related to accounting, gender and diversity can offer important foundations for a better understanding of the benefits that gender diversity and equity can bring to management and business sustainable decision-making [80].

Hence, the present study focused on the investigation of gender and age differences in correlation with Professional Accountants' behavior on accounting judgments and sustainable decision-making.

The results proved that there are significant differences between the perceptions of men and women perception regarding the aspects that influence the Professional Accountants' judgments, namely on the statements of the accounting and financial reporting regulations framework, managers' expectations regarding the financial position and performance of the enterprise and the code of ethics. We did not find correlations between age, gender and Professional Accountants' perception on the theoretical framework of professional accounting judgment, whatsoever. Nonetheless, the results showed that female accountants are more "tolerant or inclusive", more open to consult or willing to collaborate with the entity management than their male colleagues in terms of accounting options and estimates, while male accountants proved to be more skeptical about economic events and transactions. We observed that our results are line with Burke and Collins (2001) [43]. They indicate that female accountants have a more mature attitude comparing to male colleagues in the exercise of professional 
judgment, which derives from their greater inclination towards compliance with regulations, principles of professional ethics and guidelines, showing more caution in reasonings and being less attracted to risky judgments, or "roll the dice"-attitudes. They are also more open to satisfy the managers' needs of performance growth; nonetheless, this behavior can be interpreted both positively and negatively and, therefore, requires future research. For example, too much pressure from managers on the female accountants to achieve performance indicators can negatively influence accounting reasonings by altering the objectivity and neutrality of the judgment process.

What is more, whilst as the age of Professional Accountants grows, the degree of compliance with accounting regulations or standards increases also. Male accountants have a greater propensity to exercise accurate accounting judgments, considering the accounting issues related to evaluation of goodwill and assessment of borrowing costs as more important than female accountants.

All these findings may be considered a further validation of the migration from a profession with clearly masculine characteristics to a feminine one, which also impacts the professional reasoning from the perspective of gender analysis.

In relation to the findings from prior literature, we consider we were able to highlight some of the existing lights and shadows in the perceptual differences of how accountants develop professional judgments. Furthermore, the founded perceptual differences deserve further investigation into future research using a multivariate analytical approach.

Nonetheless, the results obtained cannot be generalized, Romania's data not being generalizable and, therefore, limited. Conversely, they must be interpreted according to the particularities of an emerging country such as Romania, in which the status of professional accountant differs from that of other countries depending on economic, political, socio-cultural factors, etc. In the context of the internationalization of accounting, sustainable development and mutations produced in the accounting profession, the current study can be developed through future comparative analyzes, as well as according to other similar landmarks identified in the specialized literature with reference to stereotypes and patterns.

Accordingly, even though our study has its limits, it contributes to a great extent to the development of accounting literature by examining Professional Accountants' behavior and sustainable approaches towards accounting judgments in correlation to gender diversity and age.

Several possibilities for further research in this direction have been identified through the development of this study. Future research will focus on in-depth analysis of gender stereotypes, ideologies and dissimilarities in the accounting judgment and estimates using artificial intelligence models, especially considering the context of adapting the professional accounting judgment to the vulnerabilities and uncertainties of financial and non-financial reporting caused by the challenges posed by the new Coronavirus (Covid-19) pandemic.

Author Contributions: Conceptualization, V.B. and O.I.B.; methodology and research design, V.B. and T.S.; formal analysis, D.D. and D.N.P.; investigation, D.N.P. and V.B.; writing-original draft preparation, V.B., D.D. and T.S.; writing-review and editing, D.D., O.I.B and V.B.; validation T.S. and D.N.P.; visualization, D.N.P. and D.D.; supervision, V.B. and D.D. All authors have read and agreed to the published version of the manuscript.

Funding: This research received no external funding.

Conflicts of Interest: The authors declare no conflict of interest.

\section{Appendix A}

Questionnaire

Investigation of Professional Accountants' Perceptions on Professional Accounting Judgments and Sustainable Decisions 


\section{A. GENERAL INFORMATION}

1. What is your educational profile?

Graduate of Bachelor Economic Higher Education;

Graduate of Master and Bachelor Economic Higher Education;

$\square \quad$ Graduate of Bachelor and Post-University Economic Higher Education;

$\square \quad \mathrm{PhD}$ in Economics;

$\square \quad$ Other (please detail)

2. What are your professional qualifications?
$\square \quad$ Auditor;
Chartered certified accountant (expert);
$\square \quad$ Licensed accountant;
Economist (specialized in accounting);
$\square \quad$ Authorized expert in valuation;
$\square \quad$ Tax consultant;
․ Expert in insolvency;
$\square \quad$ Other (please detail)

3. What is your practical experience in accounting?
$\square \quad$ I have no experience (I am inactive);
Under 1 year;
$\square \quad$ Between 1 and 5 years;
$\square \quad$ Between 5 and 10 years;
口 Over 10 years;
$\square \quad$ Other (please detail)

4. Which is the form of organization of the activity for the accounting services rendered by you?
$\square \quad$ Accountant as authorized person without employees;
$\square \quad$ Accountant as authorized person with employees;
$\square \quad$ Legal authorized entity without employees;
$\square \quad$ Legal authorized entity with employees;
$\square \quad$ Employee;
$\square \quad$ Other.

5. The annual income from the accounting services provided is:
I did not earn any income (I am inactive);
$\square \quad$ Under 10,000 RON/year;
Between 10,000 RON/year and 25,000 RON/year;
口 Between 25,000 RON/year and 50,000 RON/year;
口 Between 50,000 RON/year and 75,000 RON/year;
Between 75,000 RON/year and 100,000 RON/year;
․ Over 100,000 RON/year. 
6. Your age is:
$\square \quad$ Between 23 and 30 years old;
Between 30 and 35 years old;
$\square \quad$ Between 35 and 45 years old;
$\square \quad$ Between 45 and 50 years old;
․ Over 50 years old.

7. Your gender is:
$\square \quad$ male;
口 female.

\section{B. PROFESSIONAL ACCOUNTING JUDGMENT AND SUSTAINABLE ACCOUNTING OPTIONS}

8. What are the aspects you consider that significantly influence the exercise of professional accounting judgment when choosing an accounting treatment for events and transactions?

\begin{tabular}{|c|c|c|c|c|c|c|}
\hline \multicolumn{2}{|r|}{ Information } & \multirow[t]{2}{*}{$\begin{array}{l}\text { Strongly } \\
\text { Agree }\end{array}$} & \multirow[t]{2}{*}{ Agree } & \multirow{2}{*}{\multicolumn{2}{|c|}{ Neutral Disagree }} & \multirow[t]{2}{*}{$\begin{array}{l}\text { Strongly } \\
\text { Disagree }\end{array}$} \\
\hline (a) & $\begin{array}{l}\text { The statements of the accounting and financial reporting } \\
\text { regulatory framework }\end{array}$ & & & & & \\
\hline (b) & Generally accepted accounting principles & & & & & \\
\hline (c) & $\begin{array}{l}\text { Owners' expectations for obtaining the most } \\
\text { favourable dividends }\end{array}$ & & & & & \\
\hline (d) & $\begin{array}{l}\text { Managers' expectations regarding the financial position and } \\
\text { performance of the enterprise }\end{array}$ & & & & & \\
\hline (e) & $\begin{array}{l}\text { The provisions of the entity's manual of accounting policies } \\
\text { and procedures }\end{array}$ & & & & & \\
\hline (f) & Accountant's personality & & & & & \\
\hline (g) & $\begin{array}{l}\text { Accountant's professional experience, training, culture } \\
\text { and knowledge }\end{array}$ & & & & & \\
\hline (h) & Code of ethics and professional deontology & & & & & \\
\hline (i) & $\begin{array}{l}\text { Networking relationship and communication skills of the } \\
\text { accountant with the stakeholders and the entity's shareholders }\end{array}$ & & & & & \\
\hline (j) & $\begin{array}{l}\text { The accountability of the accountant in preparing financial } \\
\text { statements in line with the economic reality of transactions } \\
\text { and events }\end{array}$ & & & & & \\
\hline
\end{tabular}

9. In your view, does the implementation of accounting standards based on principles depend on the ability of accountants to exercise adequate and good quality professional judgment?

\begin{tabular}{lllll}
\hline Strongly Agree & Agree & Neutral & Disagree & Strongly Disagree \\
\hline & & \\
\hline
\end{tabular}


10. The interest pursued by professional accountants in choosing and applying accounting policies targets:

\begin{tabular}{|c|c|c|c|c|c|c|}
\hline & Interest in Choosing and Applying Accounting Policies & $\begin{array}{l}\text { Strongly } \\
\text { Agree }\end{array}$ & Agree & Neutral & Disagree & $\begin{array}{l}\text { Strongly } \\
\text { Disagree }\end{array}$ \\
\hline (a) & $\begin{array}{l}\text { Compliance with the accounting and financial } \\
\text { regulatory framework }\end{array}$ & & & & & \\
\hline (b) & $\begin{array}{l}\text { Maximize the accounting result in order to improve the entity's } \\
\text { financial position and performance }\end{array}$ & & & & & \\
\hline (c) & Minimizing the accounting result for tax optimization purposes & & & & & \\
\hline (d) & $\begin{array}{l}\text { Maintaining the financial position of the entity and } \\
\text { its performance }\end{array}$ & & & & & \\
\hline (e) & Satisfy the managers' interests to achieve the set goals & & & & & \\
\hline (f) & $\begin{array}{l}\text { Compliance with the principles of professional ethics and } \\
\text { deontology code }\end{array}$ & & & & & \\
\hline
\end{tabular}

11. Professional accounting judgment can be exercised only after all information regarding the economic or financial transaction has been collected and analysed.

\begin{tabular}{lllll}
\hline Strongly Agree & Agree & Neutral & Disagree & Strongly Disagree \\
\hline
\end{tabular}

12. Professional accounting judgment can be exercised only in the context of the existence of a general conceptual accounting framework, accounting standards or regulations.

\begin{tabular}{|c|c|c|c|c|}
\hline Strongly Agree & Agree & Neutral & Disagree & Strongly Disagree \\
\hline
\end{tabular}

13. Professional accounting judgment can be exercised only after an accurate logical judgment process has been conducted.

\begin{tabular}{lllll}
\hline Strongly Agree & Agree & Neutral & Disagree & Strongly Disagree \\
\hline
\end{tabular}

14. Does the professional accounting judgment have to be properly documented?

\begin{tabular}{lllll}
\hline Strongly Agree & Agree & Neutral & Disagree & Strongly Disagree \\
\hline
\end{tabular}

15. Choosing an accounting treatment after making professional accounting judgments will be done by consulting the management of the entity.

\begin{tabular}{lllll}
\hline Strongly Agree & Agree & Neutral & Disagree & Strongly Disagree \\
\hline & & \\
\hline
\end{tabular}


16. Does an adequate and good quality professional accounting judgment significantly influence the relevance of financial-accounting information?

\begin{tabular}{lllll}
\hline Strongly Agree & Agree & Neutral & Disagree & Strongly Disagree \\
\hline & & \\
\hline
\end{tabular}

17. Making professional judgments is a key skill of professional accountants?

\begin{tabular}{lllll}
\hline Strongly Agree & Agree & Neutral & Disagree & Strongly Disagree \\
\hline
\end{tabular}

18. Do accountants have to question economic events/transactions in order to make an accurate professional judgment?

\begin{tabular}{lllll}
\hline Strongly Agree & Agree & Neutral & Disagree & Strongly Disagree \\
\hline
\end{tabular}

19. Choose and number, in order of importance, only 5 of the following characteristics, which in your view characterize a good quality professional accounting judgment (where: 1 - very important, 2 - fairly important, 3 - important, 4 - slightly important, 5 - not at all important):

\begin{tabular}{cl}
\hline 1 & Logic appropriate accounting judgment \\
\hline 2 & Flexible appropriate accounting judgment \\
\hline 3 & Accurate appropriate accounting judgment, using only the relevant information \\
\hline 4 & Correct reasonable appropriate accounting judgment, without being altered by errors \\
\hline 5 & $\begin{array}{l}\text { Estimated reasonable appropriate accounting judgment, evaluating probabilities of } \\
\text { risks, uncertainties and ambiguities }\end{array}$ \\
\hline 6 & $\begin{array}{l}\text { Focused, reasonable appropriate accounting judgment, determines the sustainable } \\
\text { decision following a choice between several options }\end{array}$ \\
\hline 7 & $\begin{array}{l}\text { Unbiased and independent reasonable appropriate accounting judgment, without } \\
\text { being influenced by the will of managers }\end{array}$ \\
\hline 8 & $\begin{array}{l}\text { Balanced, reasonable appropriate accounting judgment, harmonizing the experience } \\
\text { with knowledge, intuition, emotions, various pressures from the internal and external } \\
\text { environment. }\end{array}$ \\
\hline
\end{tabular}

20. Which are the first words that come to mind when you hear about professional accounting judgment?
a.
b.
c.
d.
e. 
21. Appreciate the importance of performing adequate and good quality professional accounting judgment in order to assign accounting treatment to the following accounting issues (where: 1-very important, 2-fairly important, 3-important, 4-slightly important, 5-not at all important):

\begin{tabular}{ll}
\hline 1 & Estimates, changes in estimates and accounting policies \\
\hline 2 & Impairment of assets \\
\hline 3 & Revaluation of assets \\
\hline 4 & Contingent assets and liabilities \\
\hline 6 & Assessing risks and uncertainties in resource management \\
\hline 7 & Evaluation of intellectual property rights \\
\hline 8 & Assessment of intellectual capital and other non-material investments \\
\hline 9 & Assessing borrowing costs \\
\hline 10 & Evaluating the costs of restructuring the activities, in a sustainable way \\
\hline 11 & Assessment of decommissioning costs of non-current fixed assets \\
\hline 12 & Evaluation of development and innovation costs \\
\hline 13 & Estimates of employee benefits \\
\hline 14 & Estimates on deferred taxes \\
\hline 15 & Fair value valuation \\
\hline
\end{tabular}

22. To what extent do you consider that adequate professional accounting judgment is affected by the pressure of time (dead-lines)?

\begin{tabular}{lllll}
\hline To a Very Great Extent & To a Great Extent & To Some Extent & To a Small Extent & Not at All \\
\hline
\end{tabular}

23. To what extent do you consider that adequate professional accounting judgment is affected by the satisfaction of clients?

\begin{tabular}{lllll}
\hline To a Very Great Extent & To a Great Extent & To Some Extent & To a Small Extent & Not at All \\
\hline
\end{tabular}

24. To what extent do you consider that adequate professional accounting judgment is affected by the managers' expectations?

\begin{tabular}{lllll}
\hline To a Very Great Extent & To a Great Extent & To Some Extent & To a Small Extent & Not at All \\
\hline
\end{tabular}

25. List other variables (other factors) that you believe will influence the exercise of adequate accounting judgment?
a.
b.
c.
d.
e. 
26. To what extent do you consider that accounting judgments exercised in the cost accounting influences the decision-making process within the entity?

\begin{tabular}{lllll}
\hline To a Very Great Extent & To a Great Extent & To Some Extent & To a Small Extent & Not at All \\
\hline
\end{tabular}

27. To what extent do you consider that accounting judgments in cost calculation methods influences the performance of the entity?

\begin{tabular}{|c|c|c|c|c|c|}
\hline $\begin{array}{l}\text { Accounting Judgment in Cost } \\
\text { Calculation Methods }\end{array}$ & $\begin{array}{c}\text { To a Very } \\
\text { Great Extent }\end{array}$ & $\begin{array}{l}\text { To a Great } \\
\text { Extent }\end{array}$ & $\begin{array}{l}\text { To Some } \\
\text { Extent }\end{array}$ & $\begin{array}{l}\text { To a Small } \\
\text { Extent }\end{array}$ & Not at All \\
\hline \multicolumn{6}{|l|}{ Global Method } \\
\hline \multicolumn{6}{|l|}{ Order Method } \\
\hline \multicolumn{6}{|l|}{ Phase Method } \\
\hline \multicolumn{6}{|l|}{ Standard Cost Method } \\
\hline \multicolumn{6}{|l|}{ Direct Costing Method } \\
\hline \multicolumn{6}{|l|}{ Activity Based Costing Method } \\
\hline Target Costing Method & & & & & \\
\hline
\end{tabular}

\section{PERSONALITY TRAITS}

28. Do you have doubts about your ability to make right decisions?

\begin{tabular}{lllll}
\hline Always & Usually & About Half the Time & Seldom & Never \\
\hline & & \\
\hline
\end{tabular}

29. Do you tend to use a familiar approach from an earlier experience to evaluate or to judge an actual event?

\begin{tabular}{lllll}
\hline To a Very Great Extent & To a Great Extent & To Some Extent & To a Small Extent & Not at All \\
\hline
\end{tabular}

30. In conditions of uncertainty are your expectations positive?

\begin{tabular}{lllll}
\hline To a Very Great Extent & To a Great Extent & To Some Extent & To a Small Extent & Not at All \\
\hline
\end{tabular}

31. You planned an outdoor party but on the day of the event it rained heavily. What do you think?

$\square \quad$ I should have studied the weather forecast. I'm not good at organizing parties.

$\square \quad$ Tough luck. My next party will be a success.

32. Are you usually willing to assume a failure when you do something innovative?

\begin{tabular}{lllll}
\hline To a Very Great Extent & To a Great Extent & To Some Extent & To a Small Extent & Not at All \\
\hline
\end{tabular}

33. Are you usually afraid that something unexpected might ruin your plans?

\begin{tabular}{lllll}
\hline To a Very Great Extent & To a Great Extent & To Some Extent & To a Small Extent & Not at All \\
\hline
\end{tabular}


34. How often do you organize your ideas?

\begin{tabular}{lllll}
\hline To a Very Great Extent & To a Great Extent & To Some Extent & To a Small Extent & Not at All \\
\hline
\end{tabular}

35. How often do you try to create something?

$\square \quad$ Every day;

$\square \quad$ A few times a week;

$\square \quad$ A few times a month;

$\square \quad$ Once when it is full moon;

$\square \quad$ Never.

36. Do you consider yourself a persuasive person?

\begin{tabular}{lllll}
\hline To a Very Great Extent & To a Great Extent & To Some Extent & To a Small Extent & Not at All \\
\hline
\end{tabular}

37. Do you easily admit your errors?

\begin{tabular}{lllll}
\hline To a Very Great Extent & To a Great Extent & To Some Extent & To a Small Extent & Not at All \\
\hline
\end{tabular}

38. Are you usually worried about everything?

\begin{tabular}{lllll}
\hline To a Very Great Extent & To a Great Extent & To Some Extent & To a Small Extent & Not at All
\end{tabular}

39. Do you feel upset and tense if you think about the events of a day?

\begin{tabular}{lllll}
\hline To a Very Great Extent & To a Great Extent & To Some Extent & To a Small Extent & Not at All \\
\hline
\end{tabular}

40. Associate the professional accountant with a picture, for example: a tool, a color, a symbol, an animal, a song, etc. Please mention the image:

41. Associate the manager with a picture, for example: a tool, a color, a symbol, an animal, a song, etc. Please mention the image:

42. Associate the auditor with a picture, for example: a tool, a color, a symbol, an animal, a song, etc. Please mention the image:

43. Associate the accounting regulator with a picture, for example: a tool, a color, a symbol, an animal, a song, etc. Please mention the image: 


\section{References}

1. Lehman, C. We've Come a Long Way! Maybe! Re-imagining Gender and Accounting. Account. Audit. Account. J. 2012, 25, 256-294. [CrossRef]

2. UNESDOC Digital Library. UNESCO's Promise: Gender Equality, a Global Priority. 2014. Available online: https://unesdoc.unesco.org/ark:/48223/pf0000226923 (accessed on 10 April 2020).

3. United Nations Digital Library. Mainstreaming the Gender Perspective into all Policies and Programmes in the United Nations System. 2018. Available online: https://digitallibrary.un.org/record/1628167 (accessed on 10 April 2020).

4. United Nations General Assembly. Transforming Our World, The 2030 Agenda for Sustainable Development (A/RES/70/1) New York, United Nations. 2015. Available online: https://sustainabledevelopment.un.org/ post2015/transformingourworld (accessed on 10 April 2020).

5. Kabeer, N. Resources, Agency, Achievements: Reflections on the Measurement of Women's Empowerment. Dev. Chang. 1999, 30, 435-464. [CrossRef]

6. Kabeer, N. Education Is My Daughter's Future (Testimonies of Bangladeshi Women). Index Censorship 1998, 27, 154-160.

7. Pereznieto, P.; Taylor, G. A review of approaches and methods to measure economic empowerment of women and girls. Gend. Dev. 2014, 22, 233-251. [CrossRef]

8. Kabeer, N. Paid Work, Women's Empowerment and Gender Justice: Critical Pathways of Social Change; Institute of Development Studies (IDS): Sussex, UK, 2008; p. 121.

9. Kabeer, N.; Huq, L. The Power of Relationships: Love and Solidarity in a Landless Women's Organisation in Rural Bangladesh. IDS Bull. 2010, 41, 79-87. [CrossRef]

10. Kabeer, N. Between affiliation and autonomy: Navigating pathways of women's empowerment and gender justice in rural Bangladesh. Dev. Chang. 2011, 42, 499-528. [CrossRef]

11. United Nations. SDG 5-Achieve Gender Equality and Empower All Women and Girls. 2020. Available online: https://sdgs.un.org/goals/goal5 (accessed on 10 April 2020).

12. Collins, R.; Chafetz, J.S.; Blumberg, R.L.; Coltrane, S.; Turner, J.H. Toward an Integrated Theory of Gender Stratification. Sociol. Perspect. 1993, 36, 185-216. [CrossRef]

13. Treas, J.; Tai, T. Gender Inequality in Housework across 20 European Nations: Lessons from Gender Stratification Theories. Sex Roles 2016, 74, 495-511. [CrossRef]

14. Tiron-Tudor, A.; Faragalla, W.A. Women Career Paths in Accounting Organizations: Big4 Scenario. Adm. Sci. 2018, 8, 62. [CrossRef]

15. Hays Gender Diversity Report. De-gendering Gender Diversity_Improving Female Representation in the Workplace. 2017. Available online: https://www.hays.com.au/diversity/gender-diversity-report (accessed on 15 April 2020).

16. Holman, L.; Stuart-Fox, D.; Hauser, C.E. The gender gap in science: How long until women are equally represented? PLoS Biol. 2018, 16, e2004956. [CrossRef]

17. Banchefsky, S.; Park, B. Negative Gender Ideologies and Gender-Science Stereotypes Are More Pervasive in Male-Dominated Academic Disciplines. Soc. Sci. 2018, 7, 27. [CrossRef]

18. Castaño, A.M.; Lubiano, M.A.; García-Izquierdo, A.L. Gendered Beliefs in STEM Undergraduates: A Comparative Analysis of Fuzzy Rating versus Likert Scales. Sustainability 2020, 12, 6227. [CrossRef]

19. Moè, A.; Hausmann, M.; Hirnstein, M. Gender stereotypes and incremental beliefs in STEM and non-STEM students in three countries: Relationships with performance in cognitive tasks. Psychol. Res. 2020, 1, 1-14. [CrossRef]

20. Hitka, M.; Kozubíková, L.; Potkany, M. Education and Gender-Based Differences in Employee Motivation. J. Bus. Econ. Manag. 2018, 19, 80-95. [CrossRef]

21. Parker, L.D. Strategic management and accounting processes: Acknowledging gender. Account. Audit. Account. J. 2008, 21, 611-631. [CrossRef]

22. Siboni, B.; Sangiorgi, D.; Farneti, F.; De Villiers, C. Gender (in) accounting: Insights, gaps and an agenda for future research. Meditari Account. Res. 2016, 24, 158-168. [CrossRef]

23. Hines, R.D. Accounting: Filling the negative space. Accounting, Organ. Soc. 1992, 17, 313-341. [CrossRef]

24. Broadbent, J. The Gendered Nature of "Accounting Logic": Pointers to an Accounting that Encompasses Multiple Values. Crit. Perspect. Account. 1998, 9, 267-297. [CrossRef] 
25. Parker, L. Accounting historiography: Looking back to the future. Meditari Account. Res. 2015, 23, $142-157$. [CrossRef]

26. Broadbent, J. A Gender Agenda. Meditari Account. Res. 2016, 24, 169-181. [CrossRef]

27. Núñez, B.C.; Bandeira, P.; Santero-Sánchez, R. The Social Economy, Gender Equality at Work and the 2030 Agenda: Theory and Evidence from Spain. Sustainability 2020, 12, 5192. [CrossRef]

28. Bogdan, V.; Tara, I.G.; Ban, O.I. Experimental Research of Economics MA Students' Perception on the Theoretical Framework of Professional Judgment in Accounting in Connection with Individual Personality Traits. Rev. Cercet. Interv. Soc. 2016, 55, 98-111.

29. Bogdan, V.; Mester, I.T.; Gherai, D.S.; Scorte, C.M. An Analysis of the Influences of Individual Optimism, Risk Taking and Self-Confidence on Professional Accounting Judgment. J. Account. Manage. Inf. Syst. 2017, 13, 320-343.

30. Ameen, E.C.; Guffey, D.M.; McMillan, J.J. Gender differences in determining the ethical sensitivity of future accounting professionals. J. Bus. Ethic 1996, 15, 591-597. [CrossRef]

31. Sadler, E.; Barac, K. A study of the ethical views of final year South African accounting students, using vignettes as examples. Meditari Account. Res. 2005, 13, 107-128. [CrossRef]

32. Wessels, P.; Steenkamp, L. An investigation into students' perceptions of accountants. Meditari Account. Res. 2009, 17, 117-132. [CrossRef]

33. Halabi, A.; Essop, A.; Joosub, T.; Padia, N.; Vawda, M.; Yasseen, Y. A South African study comparing the effectiveness of computer-based learning materials and face-to-face teaching. Meditari Account. Res. 2010, 18, 23-37. [CrossRef]

34. Gammie, E.; Paver, B.; Gammie, B.; Duncan, F. Gender differences in accounting education: An undergraduate exploration. Account. Educ. 2003, 12, 177-196. [CrossRef]

35. Taylor, A. Ethics training for accountants: Does it add up? Meditari Account. Res. 2013, 21, 161-177. [CrossRef]

36. Callaghan, C.W.; Papageorgiou, E. Gender differences in locus of control and student performance in the South African context of accounting studies. Meditari Account. Res. 2015, 23, 348-368. [CrossRef]

37. Roos, S. Factors affecting Southern African students' success in CIMA examinations. Meditari Account. Res. 2009, 17, 48-67. [CrossRef]

38. Kirkham, L.M.; Loft, A. Gender and the construction of the professional accountant. Account. Organ. Soc. 1993, 18, 507-558. [CrossRef]

39. Anderson, J.C.; Johnson, E.N.; Reckers, P.M. Perceived effects of gender, family structure, and hysical appearance on career progression in public accounting: A research note. Account. Organ. Soc. 1994, 19, 483-491. [CrossRef]

40. Fasci, M.A.; Valdez, J. A Performance Contrast of Male and Female Owned Small Accounting Practices. J. Small Bus. Manag. 1998, 36, 1-7.

41. Radtke, R.R. The Effects of Gender and Setting on Accountants' Ethically Sensitive Decisions. J. Bus. Ethic 2000, 24, 299-312. [CrossRef]

42. Whiting, R.; Wright, C. Explaining Gender Inequity in the New Zeeland Accounting Profession. Br. Account. Rev. 2001, 33, 191-222. [CrossRef]

43. Burke, S.; Collins, K.M. Gender differences in leadership styles and management skills. Women Manag. Rev. 2001, 16, 244-257. [CrossRef]

44. Luttman, S.; Mittermaier, L.; Rebele, J. The Association of Career Stage and Gender with Tax Accountants' Work Attitudes and Behaviours. Adv. Tax. 2003, 15, 111-143.

45. Moyes, G.D.; Williams, P.A.; Koch, B. The effects of age and gender upon the perceptions of accounting professionals concerning their job satisfaction and work-related attributes. Manag. Audit. J. 2006, 21, 536-561. [CrossRef]

46. Cooper, K. Accounting by Women: Fear, Favor and the Path to Professional Recognition for Australian Women Accountants. Account. Hist. 2010, 15, 309-336. [CrossRef]

47. Dambrin, C.; Lambert, C. Mothering or auditing? The case of two Big Four in France. Accounting, Audit. Account. J. 2008, 21, 474-506. [CrossRef]

48. Komori, N. Towards the feminization of accounting practice. Account. Audit. Account. J. 2008, 21, 507-538. [CrossRef]

49. Gammie, E.; Whiting, R. Women accountants: Is the grass greener outside the profession? Br. Account. Rev. 2013, 45, 83-98. [CrossRef] 
50. Carmona, S.; Ezzamel, M. Accounting and lived experience in the gendered workplace. Account. Organ. Soc. 2016, 49, 1-8. [CrossRef]

51. Gallego-Álvarez, I.; García-Sánchez, I.-M.; Domínguez, L.R. The influence of gender diversity on corporate performance. Rev. Contab. 2010, 13, 53-88. [CrossRef]

52. Khalife, D.; Chalouhi, A. Gender and business performance. Int. Strat. Manag. Rev. 2013, 1, 1-10. [CrossRef]

53. Rose, C. Does female board representation influence firm performance? The Danish evidence. Corp. Governance: Int. Rev. 2007, 15, 404-413. [CrossRef]

54. Barua, A.; Davidson, L.F.; Rama, D.V.; Thiruvadi, S. CFO Gender and Accruals Quality. Account. Horizons 2010, 24, 25-39. [CrossRef]

55. Peni, E.; Vahamaa, S. Female Executives and Earnings Management. Manag. Finance 2010, 36, $629-645$.

56. Francis, B.; Hasan, I.; Park, J.C.; Wu, Q. Gender Differences in Financial Reporting Decision-Making: Evidence from Accounting Conservatism. Contemp. Account. Res. 2015, 32, 1-61. [CrossRef]

57. Weeks, W.A.; Moore, C.W.; McKinney, J.A.; Longenecker, J.G. The Effects of Gender and Career Stage on Ethical Judgment. J. Bus. Ethic 1999, 20, 301-313. [CrossRef]

58. Roxas, M.L.; Stoneback, J.Y. The Importance of gender Across Cultures in Ethical Decision-making. J. Bus. Ethic 2004, 50, 149-165. [CrossRef]

59. Ho, S.S.M.; Li, A.Y.; Tam, K.; Zhang, F. (Frank) CEO Gender, Ethical Leadership, and Accounting Conservatism. J. Bus. Ethic 2014, 127, 351-370. [CrossRef]

60. Odar, M.; Jerman, M.; Jamnik, A.; Kavčič, S. Accountants' ethical perceptions from several perspectives: Evidence from Slovenia. Econ. Res. Ekon. Istraž. 2017, 30, 1785-1803. [CrossRef]

61. Conroy, S.J.; Emerson, T.L.; Pons, F. Ethical Attitudes of Accounting Practitioners: Are Rank and Ethical Attitudes Related? J. Bus. Ethic 2009, 91, 183-194. [CrossRef]

62. Galizzi, G.; Siboni, B. Positive action plans in Italian universities: Does gender really matter? Meditari Account. Res. 2016, 24, 246-268. [CrossRef]

63. Baldarelli, M.G.; Del Baldo, M.; Vignini, S. Pink accounting in Italy: Cultural perspectives over discrimination and/or lack of interest. Meditari Account. Res. 2016, 24, 269-292. [CrossRef]

64. Emerson, T.L.; Conroy, S.J.; Stanley, C.W. Ethical Attitudes of Accountants: Recent Evidence from a Practitioners' Survey. J. Bus. Ethic 2006, 71, 73-87. [CrossRef]

65. St Pierre, K.; Nelson, E.; Gabbin, A. A Study of the Ethical Development of Accounting Majors in Relation to Other Business and Nonbusiness Disciplines. Account. Educ. J. 1990, 3, 23-35.

66. Barnett, T.; Bass, K.; Brown, G. Ethical ideology and ethical judgment regarding ethical issues in business. J. Bus. Ethic 1994, 13, 469-480. [CrossRef]

67. Hair, J.F., Jr.; Hult, G.T.M.; Ringle, C.; Sarstedt, M. A Primer on Partial Least Squares Structural Equation Modeling (PLS-SEM); Sage Publications: Thousand Oaks, CA, USA, 2016.

68. Joshi, A.; Kale, S.; Chandel, S.; Pal, D. Likert Scale: Explored and Explained. Br. J. Appl. Sci. Technol. 2015, 7, 396-403. [CrossRef]

69. Santos, J.R.A. Cronbach's Alpha: A Tool for Assessing the Reliability of Scales. J. Ext. 1999, 37, 1-5.

70. Abdi, H.; Williams, L.J. Principal Component Analysis. Wiley Interdiscip. Rev. Comput. Stat. 2010, 2, $433-459$. [CrossRef]

71. Pearson, K. On the Criterion that a Given System of Deviations from the Probable in the Case of a Correlated System of Variables is Such that it Can be Reasonably Supposed to have Arisen from Random Sampling. In Multiple Testing Procedures with Applications to Genomics; Springer Science and Business Media LLC: Berlin, Germany, 1992; pp. 11-28.

72. Istrate, C. Gender Issues in Romanian Accounting Profession. Rev. Econ. Bus. Stud. 2012, 5, 21-45.

73. Albu, N.; Albu, C.; Girbina, M.; Sandu, M. The Implications of Corporate Social Responsibility on the Accounting Profession: The Case of Romania. Amfiteatru Econ. 2011, 13, 221-234.

74. Ticoi, C.-F.; Albu, N. What factors affect the choice of accounting as a career? The case of Romania. J. Account. Manag. Inf. Syst. 2018, 17, 137-152. [CrossRef]

75. Del Baldo, M.; Tiron-Tudor, A.; Faragalla, W.A. Women's Role in the Accounting Profession: A Comparative Study between Italy and Romania. Adm. Sci. 2018, 9, 2. [CrossRef]

76. Tiicoi, C.F. Women in Accountancy. The Case of Romania. The Annals of the University of Oradea. Econ. Sci. 2019, 28, 203-213. 
77. Groff, M.Z.; Slapnicar, S.; Stumberger, N. The Influence of Professional Qualification on Customer Perceptions of Accounting Services Quality and Retention Decisions. J. Bus. Econ. Manag. 2014, 16, 753-768. [CrossRef]

78. KPMG. Elevating Professional Judgment in Auditing and Accounting: The KPMG Professional Judgment Framework. 2011. Available online: https:/www.kpmguniversityconnection.com/University/view/ curriculum/?module_id=40 (accessed on 10 April 2020).

79. Haynes, K. Moving the Gender Agenda or Stirring Chicken's Entrails? Where Next for Feminist Methodologies in Accounting? Account. Audit. Account. J. 2008, 21, 539-555. [CrossRef]

80. Naranjo, D.; Espejo, C.Á.-D.; Gallego, A.C. The relationship between diversity, gender and accounting. Rev. Contab. 2010, 13, 9-15. [CrossRef]

(C) 2020 by the authors. Licensee MDPI, Basel, Switzerland. This article is an open access article distributed under the terms and conditions of the Creative Commons Attribution (CC BY) license (http://creativecommons.org/licenses/by/4.0/). 